\title{
COMMUNiTY AGREEMENTS AND MINING: A NEW FRONTIER FOR SOCIAL IMPACT INVESTMENTS
}

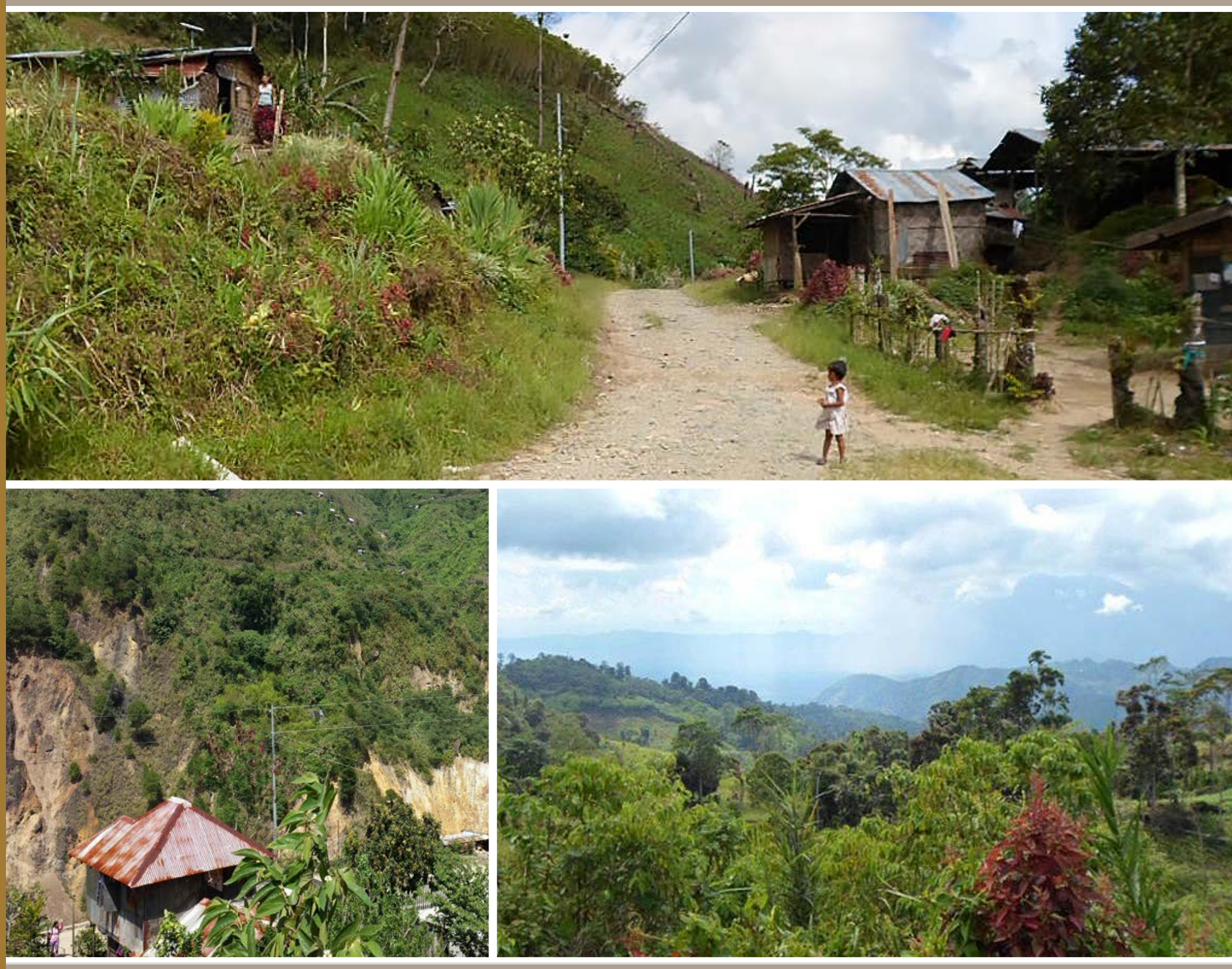

M. Cecilia G. Dalupan | December 2015

A RTC Impact Fund and One Earth Future Discussion Paper 


\section{ACKNOWLEDGMENTS}

This report is the product of a research collaboration between One Earth Future Foundation and the RTC Impact Fund. We would like to acknowledge the assistance of OEF research associate Ambika Chawla, who developed supporting country reports for Ghana,

Guatemala, and Papua New Guinea.

We would also like to acknowledge the contributions of the project's collaborating institutions in the Philippines: the Ateneo de Manila School of Government headed by Dean Antonio G.M. La Viña and supported by Atty. Nicole Torres, and Puno and Puno Law Offices represented by Senior Partner Julito Sarmiento.

Finally, we would also like to express our sincere thanks to the different participants in the Philippines from government institutions, civil society, industry, and the communities of Balatoc and Tampakan, who were involved in project consultations and who generously shared their time, expertise, and perspectives.

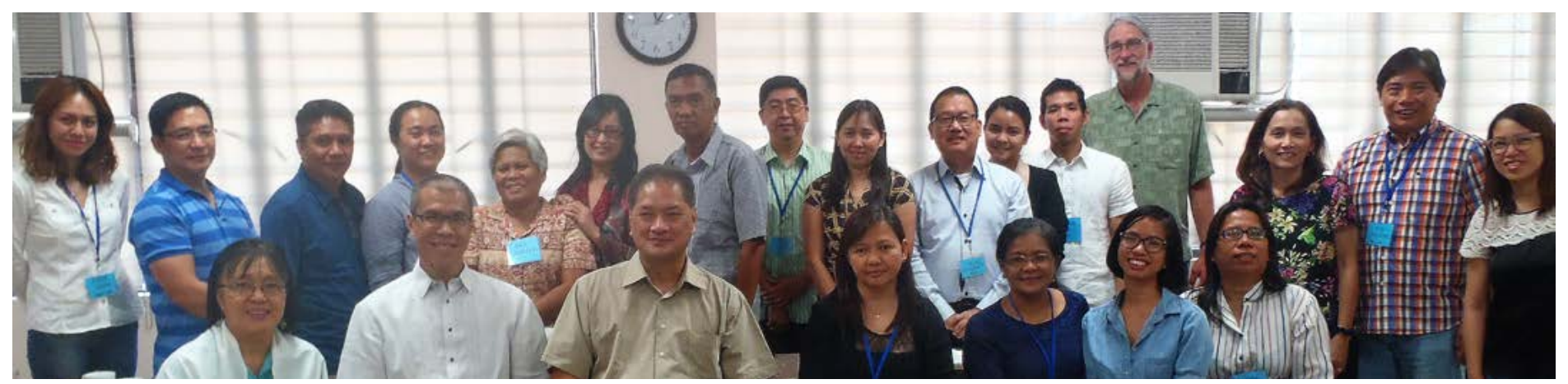

OEF-RTC Impact Fund Multi-Sectoral Roundtable Discussion in the Philippines

The RTC Impact Fund is a full spectrum philanthropic grantmaker and social impact investor that supports communities seeking to harness their natural resources for equitable sustainable development.

One Earth Future Foundation leads initiatives to improve systems and services that prevent armed conflict.

The OEF discussion paper series provides thought-provoking perspectives on contemporary issues related to peace and security. Although we believe that the papers in this series make a valuable contribution to the public discourse, they do not necessarily reflect $\mathrm{OEF}$ opinion. 


\section{TABLE OF CONTENTS}

ABBREVIATIONS

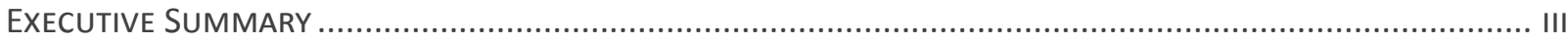

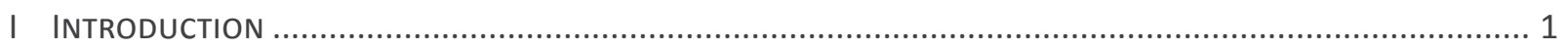

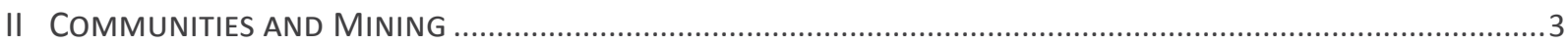

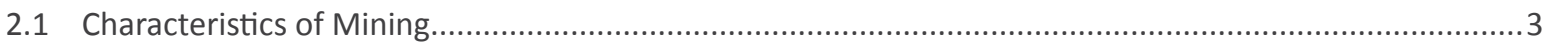

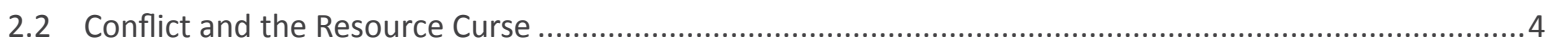

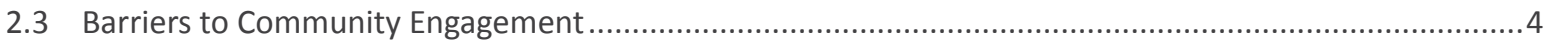

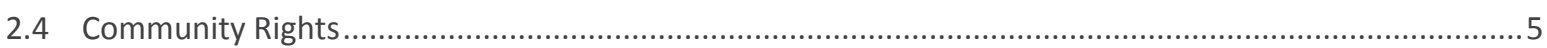

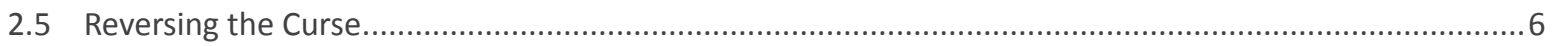

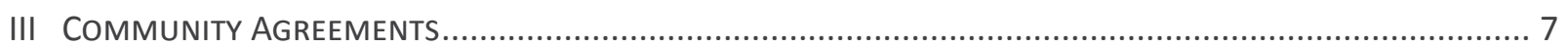

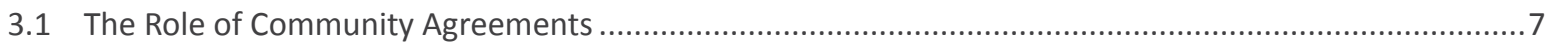

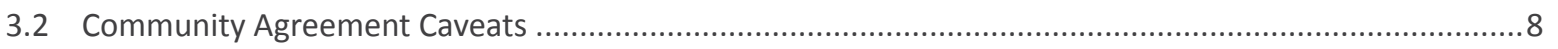

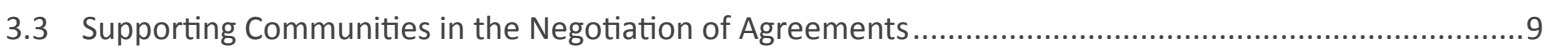

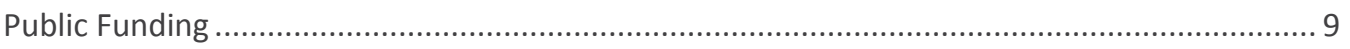

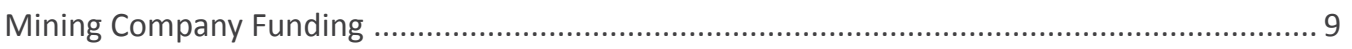

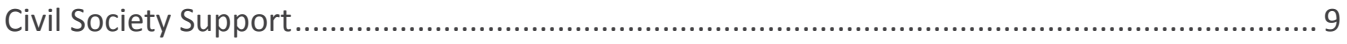

Social Impact and Program-Related Investments ........................................................ 10

IV IMPACT INVESTMENTS TO SUPPORT THE NEgotiation OF COMMUNity AgREEMENTS:

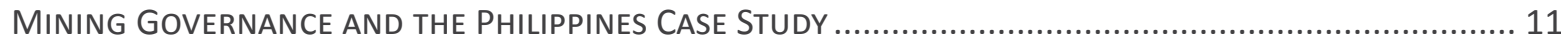

4.1 An Overview of Select Mining Governance Jurisdictions ............................................................11

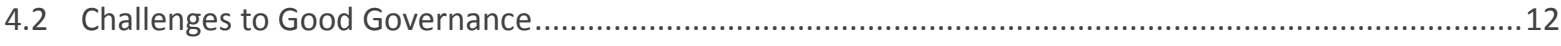

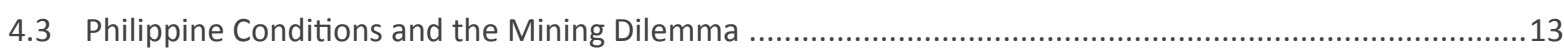

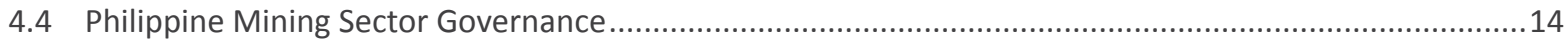

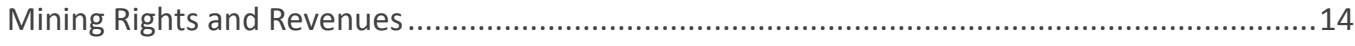

Revenue Allocation: National and Local Governments .....................................................15

Mining in Ancestral Domains and Lands:

Free Prior and Informed Consent and Memoranda of Agreement ....................................16

Mining and Non-Indigenous Communities ...............................................................

4.5 Implementation Issues in FPIC Processes and MOA Negotiations ..................................................17

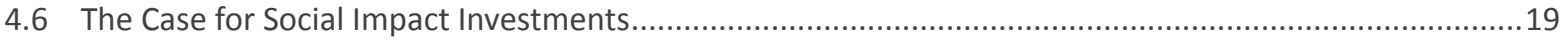

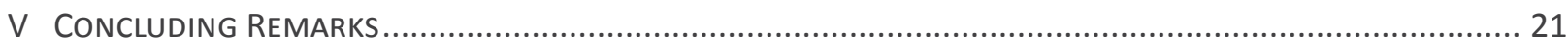


ii | Community Agreements and Mining: A New Frontier for Social Impact Investments

\section{ABBREVIATIONS}

\begin{tabular}{|c|c|}
\hline ADSDPP & Ancestral Domain Sustainable Development Protection Plan \\
\hline CSO & Civil society organization \\
\hline DENR & Department of Environment and Natural Resources \\
\hline EIA & Environmental Impact Assessment \\
\hline EITI & Extractive Industries Transparency Initiative \\
\hline FPIC & Free Prior and Informed Consent \\
\hline FTAA & Financial and Technical Assistance Agreement \\
\hline GDP & Gross Domestic Product \\
\hline $\mathrm{Ha}$ & hectare \\
\hline IPRA & Indigenous Peoples Rights Act \\
\hline IFC & International Finance Corporation \\
\hline LGU & Local Government Unit \\
\hline MGB & Mines and Geosciences Bureau \\
\hline MICC & Mining Industry Coordinating Council \\
\hline MOA & Memorandum of Agreement \\
\hline MPSA & Mineral Production Sharing Agreement \\
\hline $\mathrm{NCIP}$ & National Commission on Indigenous Peoples \\
\hline NPA & New People's Army \\
\hline PNG & Papua New Guinea \\
\hline PRI & Program-related investment \\
\hline SDMP & Social Development Management Program \\
\hline UNDP & United Nations Development Programme \\
\hline
\end{tabular}




\section{EXECUTIVE SUMMARY}

One Earth Future Foundation and RTC Impact Fund developed this study to explore the role that an impact investment fund may have in the negotiation of mining-related community agreements. Key insights below were discussed, arising from a review of relevant literature in select jurisdictions, with specific focus on the Philippines, where the free, prior, and informed consent of indigenous communities to mining is legally required, as are community agreements with companies.

\section{MINING AND SOCIAL CONFLICT}

- Developing countries are increasingly becoming mineral producers and targets for exploration. This inevitably involves large-scale land use, particularly in remote rural areas near or inhabited by local communities.

- Large-scale mining disproportionately affects communities that depend upon the land and natural resources for their ways of life and livelihoods. Their interests are typically unrepresented or under-represented in development decisions, with mining revenues and other economic benefits vulnerable to elite capture and corruption. Inadequate social and environmental protections, insecure land rights, and capacity constraints are principal barriers to community engagement.

- Failure to engage communities and appropriately address legal, social, environmental, and technical aspects of a mining project are sources of social tension, with issues around the control over minerals sometimes exacerbating armed conflicts. The "resource curse," characterized by the paradox of poverty in certain resource-rich nations, is essentially a failure of governance that is often rooted in the disparate capacities and bargaining powers of companies, communities, and governments.

\section{SUSTAINABLE DEVELOPMENT AND COMMUNITY AGREEMENTS}

- International principles suggest that sustainable investments are those that uphold human rights and integrate socioeconomic and environmental concerns in processes and in substantive outcomes. Democratic governance means that affected communities must have the ability to convey their concerns and to evaluate the comprehensive costs and benefits of a project, including the option of non-extraction.

- Where a decision is made to go forward with a mining project, effective governance relies on the extent to which standards of sustainable development are incorporated in a country's policies and legal framework, and on the capacity of stakeholders to enforce these standards. This requires active, transparent, and informed collaboration by governments, mining investors, and concerned communities.

- While community or benefit agreements are not required consistently across jurisdictions, they are considered best practices under international principles and standards relevant to mining. For communities, these can demonstrate recognition and respect for their rights, incorporate social and environmental protections, and facilitate economic benefits. For companies, they can facilitate consultations, demonstrate community support, and provide project stability.

- Effective and equitable community agreements are possible only through thorough and informed negotiations. Local communities are often at a disadvantage given their unfamiliarity with mining, limited awareness of their rights, and lack of financial resources to represent themselves. Communities must have the ability to negotiate on fair terms and benefit equitably from extractive processes.

\section{THE PHILIPPINES CASE STUDY}

- National legal frameworks address whether and to what extent mining is allowed, under what conditions, and for whose benefit. These issues are particularly challenging in countries like the Philippines-rich in mineral resources but also 
stressed by biodiversity loss, competing uses of limited land areas, corruption, and the needs of a growing population. The country's legal framework incorporates socioeconomic and environmental safeguards, including the requirement that mining companies obtain the free prior and informed consent of concerned indigenous peoples and, if obtained, the payment of royalties. Mining companies are also required to enter into agreements with host and neighboring communities relating to social programs such as enterprise development, education, and health services.

- The effectiveness of these safeguards is hampered by legal and enforcement challenges that include the insecurity of customary titles, uncertainty in revenue- and benefit-sharing arrangements, lack of information about and monitoring of agreements, and limited enforcement capacity. Likewise, among communities, there is limited knowledge and understanding of mining operations, which adversely impacts the capacity to assert their rights and interests, negotiate equitable agreements on terms that maximize benefits, monitor parties' compliance with agreed-upon responsibilities, and sustainably manage mine revenues.

- In the context of legal, regulatory, and information gaps as well as institutional capacity constraints, community agreements are potentially the most appropriate mechanism for addressing uncertainties and protecting the community's interests, provided these clarify rights and responsibilities and adhere to international standards and best practices on revenue allocation, compensation and benefits, compliance monitoring, and trust fund management, among other considerations.

\section{FUNDING OPTIONS FOR COMMUNITY NEGOTIATIONS}

- There are inadequate funding sources and programs available to support communities in gaining expertise and a place at the table to negotiate with companies and governments regarding mining projects. Available funding is limited, and typically comes from multilateral financing institutions or private foundations and is directed to or through governments. Company funding that may be available raises conflicts of interest and questions of independence.

- It is necessary to find appropriate ways to provide independent and competent legal advice to affected communities. Thus, the opportunity arises to engage social entrepreneurs and impact investors to support capacity-building programs and to establish a market mechanism that can provide financing options for communities to acquire the legal, financial, and technical tools they need to negotiate community agreements.

- Impact investing refers broadly to efforts by both individual and institutional investors to generate measurable social benefits in addition to financial returns. It seeks to leverage private resources to create positive social impacts, such as environmental protection and poverty alleviation. It has the potential to complement philanthropy and other sources of funding in order to catalyze positive change anywhere in the world.

- An impact investment fund would source capital from social investors in order to extend financing to communities to build capacity and retain competent, credible legal and other advisers to negotiate on a knowledgeable, professional, and equal basis with mining companies and governments.

Establishing an impact investment fund and collaborating with communities, investors, and other stakeholders to operationalize its vision will be challenging. A great deal of work will need to be sustained, including developing operational structures, criteria, and processes. These will be necessary in order to enable social impact investments as a viable and appropriate financing option through which interested communities can obtain the independent and competent legal advice to assert their rights, negotiate community agreements in furtherance of their interests, build the capacity to manage mine revenues, foster genuine partnerships with companies and other stakeholders, and equitably share benefits. These conditions can ultimately help prevent conflict and contribute to sustainable development and peace. 
Back to Table of Contents

Community Agreements and Mining: A New Frontier for Social Impact Investments $\mid 1$

\section{INTRODUCTION}

Developing countries and emerging economies are increasingly becoming major producers and consumers of metals. Chile, Peru, and the Democratic Republic of Congo, for example, are among the world's leading copper-producing countries. ${ }^{1}$ South Africa and Mexico are major producers of gold, while China leads in the production of 44 commodities, including gold, copper, aluminum, and iron ore. ${ }^{2}$ Despite cyclical commodity prices, minerals remain a major driver for almost every facet of modern life, from steel for buildings and copper to conduct electricity, to the materials for wind turbines and solar panels for renewable energy.

As mining investments expand geographically into the developing world, they also result in greater impacts on agricultural lands, forests, and traditional areas inhabited by or relied upon by communities. This has, in turn, given rise to socioeconomic, environmental, and human rights issues, with disputes concerning control over minerals at times exacerbating armed conflicts. ${ }^{3}$ Today's technology allows for both the instantaneous reporting of local conflicts and greater scrutiny of mining operations, and within the mining industry ${ }^{4}$ itself, community-related issues are considered to be among the most serious challenges to a mining project. ${ }^{5}$

International initiatives relevant to extractive industries advocate local engagement, empowerment, and community agreements as hallmarks of sustainable development. If negotiated effectively and in good faith, agreements between companies and communities can demonstrate mutual recognition and respect, incorporate human rights protections, and facilitate socioeconomic benefits. Moreover, the negotiation process, together with the implementation and monitoring of the agreement, would embody capacitybuilding elements for communities.

The exclusion and ineffective representation of communities, however, are sources of conflict around mining projects, particularly in the developing world. A key challenge is ensuring that communities have access to the legal, technical, and other services needed to assert their interests, negotiate better deals, and establish appropriate mechanisms for receiving, managing, and growing economic benefits.

Currently, there is inadequate funding for communities to gain a place at the table and the capacity to negotiate with companies and governments on a level field. Funds may be available from multilateral institutions, companies, and philanthropic sources, but these are limited and are typically directed to, or through, governments. Moreover, these are often sufficient only to support short-term programs.

Rather than having communities rely on grants from these traditional funding sources, the opportunity arises to explore the role that social impact investments can have in community negotiations. The theory of change is that access to new, innovative, and earlystage financing options can empower communities and strengthen their capacity to participate more actively in development decisions, negotiate fair and equitable project-related agreements, and sustainably manage economic benefits.

This study was developed by One Earth Future Foundation and the RTC Impact Fund to assess the relevance of and potential for social impact investments to support mining-affected communities in developing countries. It involved a review of relevant literature, including international legal instruments and reports, as well as industry and civil society publications. A review of select countries was also undertaken; namely, the Philippines, Ghana, Guatemala, and Papua New Guinea. These countries have democratic institutions in place, but face financial and technical capacity constraints in

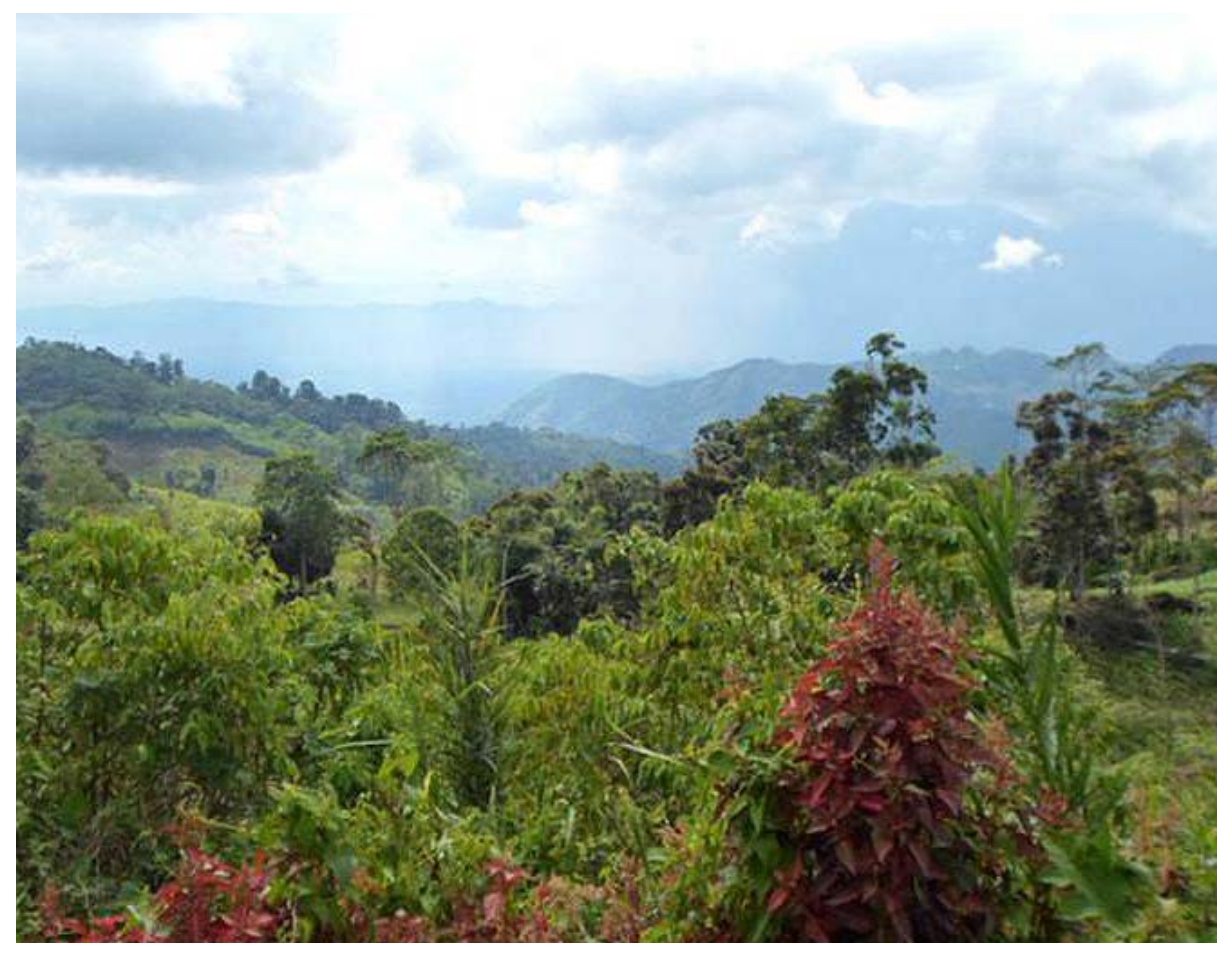

Tampkan, South Cotabato 


\section{COMMUNITIES AND MINING}

The key stakeholders in a mining project are typically the mining investor and mine operator, the national and local governments, and communities. "Local communities" generally refers to groups living near a project or potentially affected by it. The failure of a company to exercise due diligence in stakeholder analysis or to engage the affected community are potential sources of social conflict.

\subsection{CHARACTERISTICS OF MINING}

Mining projects pose significant challenges for communities, given their unique aspects and characteristics.

\section{LEGAL ISSUES}

- In virtually all countries, the state asserts ownership over sub-surface mineral resources, and many jurisdictions treat mining rights as dominant or superior to surface rights.

- Mining concessions and agreements have typically involved only two parties: the government as the mineral owner, and companies as investors. Communities are not parties to these contracts.

\section{TECHNICAL IsSUES}

- Mining is site-specific; the design and siting of facilities and operations are dictated by the location and type of deposit.

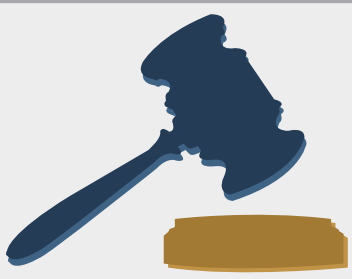

\section{ENVIRONMENTAL \&} SOCIAL IMPACTS

- Environmental and

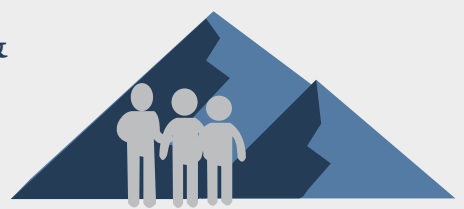
social impacts vary, depending on the scale and extent of operations, the processes and chemicals used, and the mitigation efforts of operators.

- These impacts are inevitable and often irreversible, ranging from dust and noise to changing the quality and use of, and access to, resources.

- Environmental and social issues can continue long after mine closure.

\section{ECONOMICS AND EMPLOYMENT}

- A mining project has

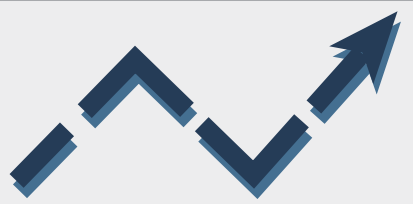
a delayed and finite revenue stream. Revenue is generated during production, which can begin years after exploration, and ceases upon closure.

The project may be carried out in a number of ways, including open pit mining, mountaintop removal, or underground mining.

- The site-specific nature of mining can mean that facilities or earthworks may be located on inhabited areas, which in turn may displace individuals or even entire communities.

- A mine project entails several phases, including exploration, construction, production, and closure. Their length and extent vary, depending on legal, technical, economic, and other factors.

- The life and scale of a mine project vary depending on technical and economic issues; its footprint can be limited or expansive, and it can be operational for years or even many decades.
- The cyclical nature of commodity prices means revenues may be uneven or inconsistent throughout the life of the mine.

- The jurisdiction's law or the mining agreement between the government and the investor provides the project's fiscal regime. This may not include provisions on compensation or benefits for communities.

- Project and asset transfers are not uncommon in the mining sector, which may bring about changes in staff, management, and operations.

- Mining jobs for unskilled community members will be available mostly during construction. Fewer jobs, often requiring more technical skills and training, are available during the typically longer production phase, when environmental impacts continue and may even increase. 
Gaining social acceptance for a mining project is not possible without addressing the issues that arise from these different aspects. Communities have the right to be informed, for example, about where facilities will be built and why, where the minerals will be processed, and the jobs that will be available. Revenue issues are critical; if governed properly, mining royalties, taxes, and other revenues can fund local infrastructure development, improve basic services, and drive economic growth. But across many developing countries, mining revenues go largely to the central coffers, and the extent to which benefits flow to affected local areas remains a source of conflict.

Fundamentally, social conflicts convey a loss of control: they are foreseeable, if not inevitable, when a community feels that it has no control, nor even a voice in decisions impacting them. A company, on the other hand, may also fear losing control of the project scope and timeline if they agree to continuous engagement with the affected communities. ${ }^{6}$ It is suggested, however, that early and continuous engagement between companies and communities is the better paradigm.

Companies should engage with communities early on in the exploration phase and jointly define the process, agenda and timelines for their dialogue. They should also be open to engaging community representatives in the actual planning process for the project, rather than focus on obtaining community approval once the project plan has been finalized internally. Risks and uncertainties related to the project (e.g. the potential impact of exploration results or changing global market conditions) should be openly discussed. This dialogue should take into account not only the next few years, but the entire life-cycle of the project. ${ }^{7}$

\subsection{CONFLICT AND THE RESOURCE CURSE}

In countries where there is a wealth of natural resources but governance is weak or corrupt, communities may become even more disenfranchised and impoverished, leading to destructive development and even violent conflict. These conditions contribute to the "resource curse," the paradoxical situation in which resource-rich nations find large segments of their populations still mired in poverty. A World Bank study revealed, for example, that while oil production led to increased GDP in Angola, the Democratic Republic of Congo, and Gabon, "the benefits of growth have not reached the poorest segments of society," and poverty in affected areas actually increased. ${ }^{8}$

\section{d}

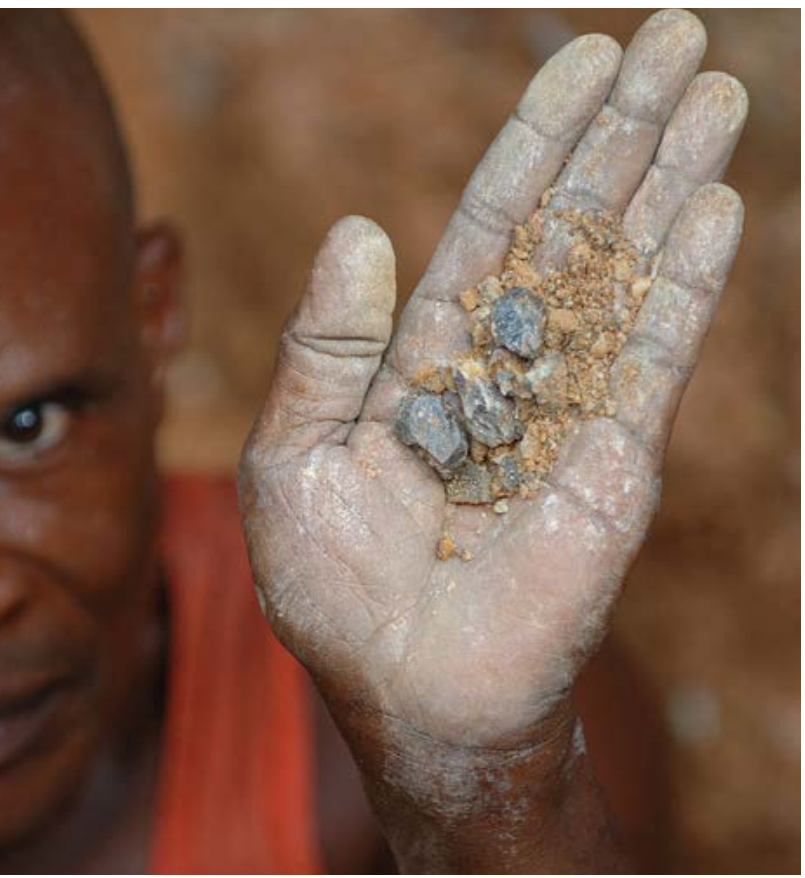

The potential for extractive industries like mining to exacerbate conflict has been called the "violent form of the resource curse," and can occur especially in areas marked by insurgencies and militarization. ${ }^{9}$ Where armed anti-state actors and mining projects co-exist, companies are often faced with having to pay the former to avoid disruptions, or with having to seek protection from military or paramilitary groups. Funds extorted by insurgent groups can then be used to purchase more weapons, while a militarized environment can intimidate local communities. The situation is particularly precarious where ill-trained military or security personnel equate community opposition with insurgency, or where anti-state actors target community members they perceive to be collaborating with companies.

The resource curse is fundamentally a failure of governance, often rooted in the impoverishment of communities affected by resource projects and their disparate capacities vis-à-vis companies and governments. In the case of a mining project, effective governance involves the active, transparent, and informed collaboration of stakeholders; principally, the government, the mining investor, and affected communities.

\subsection{BARRIERS TO COMMUNITY ENGAGEMENT}

Various studies have focused on the factors that prevent communities from participating in development decisions concerning mining and other extractive projects. These include the lack of legal rights, language barriers, poor literacy, limited access to information, 
participation risks, and cultural barriers. ${ }^{10}$ Legal barriers may include lack of clear or formal land rights and fear of expropriation, or lack of legal identity. Costs of engagement may include transportation or travel expenses to meetings as well as foregone work or income. Participation risks may arise if there are coercive elements or pressures on communities to support a particular decision, while cultural barriers may include hierarchical structures that prevent community members from having equal participation.

Mining investments require access to land and security of land tenure in order to ensure their access remains undisturbed. As minerals are typically owned by the state, governments may grant a company mining rights that include access to and use of lands inhabited by local or indigenous communities. These communities often do not have formal rights to the lands they occupy and use, while indigenous communities may have traditional rights that are undocumented or are not respected. Many of these communities are entirely dependent on the land and resources for their livelihoods and cultural identities. They are often disproportionately affected by mining and other extractive industries.

Too often, community lands, rivers and ecosystems are despoiled and communities displaced by mining activities. Enormous industrial wastelands are created from vast open pit mines and mountain top removal; voracious use and poisoning of water systems; deforestation; contamination of precious topsoil; air pollution; acid leaching; cancer clusters - the catalogue of devastation is relentless and growing. The rights of farming, pastoralist and indigenous communities are threatened. ${ }^{11}$

An important environmental and social safeguard is the Environmental Impact Assessment (EIA), a standard requirement of most legal frameworks. This generally requires that a mining investor consult with stakeholders, and in certain cases, seek the consent of indigenous communities. If this and other safeguards are weak or ineffectively enforced, local communities will be unrepresented in development decisions; their interests can be subverted by those with political or economic power, rendering any benefits vulnerable to elite capture and corruption.

Of the different stakeholders in a mining project, communities in poor, remote rural locations are at the greatest disadvantage due mainly to their lack of capacity. They are generally unfamiliar with large, technical projects and historically, in many cases, if not most, they have been excluded from development decisions affecting them. They often have weak or ineffective community structures, low awareness of their rights, little to no access to the social and environmental protections provided by law, and limited resources to build capacity and assert their interests.

\subsection{COMMUNITY RIGHTS}

Basic protections under human rights instruments extend to all communities, including the Universal Declaration of Human Rights (1948), the International Covenant on Civil and Political Rights (1966), the International Covenant on Economic, Social and Cultural Rights (1966), and the Convention on the Elimination of All Forms of Discrimination Against Women (1979). Examples of similar regional instruments include the European Convention for the Protection of Human Rights and Fundamental Freedoms (1950), the American Convention on Human Rights (1969), and the African Charter on Human and Peoples' Rights (1981).

Among the more recent and influential instruments applicable to the mining sector are the Voluntary Principles on Security and Human Rights (2000) and the United Nations Guiding Principles on Business and Human Rights (2011). Developed by governments, extractive industries, and non-governmental organizations, the Voluntary Principles provide guidance on company assessment of security risks and the potential for human rights abuses, and on engagement with security providers, including the military, law enforcement, and private security. ${ }^{12}$ 
Back to Table of Contents

6 | Community Agreements and Mining: A New Frontier for Social Impact Investments

The Guiding Principles establish the Protect-Respect-Remedy framework and outline the responsibilities of governments and commercial actors. ${ }^{13}$ Pursuant thereto, businesses must avoid causing or contributing to adverse human rights impacts through their activities, must address such impacts when they occur, and must seek to prevent or mitigate adverse human rights impacts that are directly linked to their operations, products, or services by their business relationships, even if they have not contributed to those impacts. Both sets of principles enjoy widespread multi-sectoral support, and both have been incorporated in, among others, the Guidelines for Multinational Enterprises of the Organisation for Economic Cooperation and Development and the International Finance Corporation (IFC) Performance Standards on Environmental and Social Sustainability.

Various conventions specifically set forth the rights and protections of indigenous peoples. ${ }^{14}$ These include International Labor Organization Convention No. 169 (1989) (ILO 169), the International Convention on the Elimination of All Forms of Racial Discrimination (1965), the Convention on Biological Diversity (1992), and the UN Declaration on the Rights of Indigenous Peoples (2007).

These instruments recognize the individual and collective rights of indigenous peoples, including the right to self-determination and cultural integrity; rights regarding their lands, territories, and natural resources; the right to culturally-appropriate development; and the right to be consulted with respect to mining and other development activities within their traditional lands.

The rights of indigenous peoples are also recognized by multilateral institutions. The IFC Performance Standards require the FPIC of indigenous peoples in cases of relocation and impact on lands and natural resources subject to traditional ownership or under customary use. These standards form the basis of the Equator Principles which are applied by 81 banks and investment entities that finance more than $70 \%$ of projects in emerging markets. ${ }^{15}$

The International Council on Mining and Metals is the industry association comprised of major companies, national and regional mining associations, and global commodity associations. It released an updated Good Practice Guide on Indigenous Peoples and Mining in 2015, reiterating its 2013 Position Statement that includes the commitment to seek the consent of indigenous peoples for new projects and changes to existing projects on lands they traditionally own or use, and which are likely to have significant adverse impacts on them. ${ }^{16}$ The 2013 Policy Statement also noted that member companies may choose to extend this commitment to non-indigenous peoples. $^{17}$

While there is increasing recognition of the right to consultation and FPIC in cases of displacement, a general FPIC requirement for development activities is far less established. In mining projects across the globe, human rights principles and the rights specific to indigenous peoples are unevenly applied.

\subsection{REVERSING THE CURSE}

The resource curse is not inevitable, and literature points to countries such as Norway and Botswana that have established effective mechanisms of governance, diversifying their economies and achieving consistent growth. ${ }^{18} \mathrm{~A}$ sustainable and successful mining project will need to meet not only traditional geological, economic, technical, financial, and legal criteria; a "social license" is equally important. This is:

\footnotetext{
... an unwritten social contract. Unless a company earns that license, and maintains it on the basis of good performance on the ground, and community trust, there will undoubtedly be negative implications. Communities may seek to block project developments; employees may choose to work for a company that is a better corporate citizen; and projects may be subject to ongoing legal challenge, even after regulatory permits have been obtained, potentially halting project development. ${ }^{19}$
}

The term "social license" may give the erroneous impression that it is static, obtained after completion of a clear-cut set of procedures, after which a permit is issued with a fixed term. On a deeper level, however, it refers to a privilege to proceed with an activity that is the result of meeting certain conditions of conduct, and that carries with it responsibilities for continued validity. A social license to operate is essentially a compact among key stakeholders, founded on a relationship of trust and respect. The next section will examine the concept of sustainable investments in the mining sector and the importance of a social compact embodied in community agreements. 
Back to Table of Contents

Community Agreements and Mining: A New Frontier for Social Impact Investments | 7

\section{COMMUNITY AGREEMENTS}

Many countries and communities are dealing with the challenges of balancing mineral extraction with environmental values and the needs of different stakeholders. This may mean that that a mine design should be adjusted, or that mining may not be the optimum development option. Given the complexity of these issues, governance that is democratic and empowered means that stakeholders, especially communities, must have the ability to effectively convey their concerns and evaluate the costs and benefits of a project. Stakeholders must recognize that non-extraction is a valid option.

Stakeholders consulted in the Philippines noted that Wealth Accounting and Valuation of Ecosystem Services, or WAVES, may help clarify options by providing more comprehensive values for ecosystem services and mining projects..$^{20}$ At the same time, some noted that cultural values are not quantifiable but should be similarly recognized. ${ }^{21}$

Where a decision is made to go forward with a mining project, effective governance will rely heavily on the extent to which sustainable development standards are enforced in the negotiation and implementation of mining and community agreements. A number of international multi-stakeholder initiatives have established standards relevant to mining, including the Initiative for Responsible Mining Assurance and the Extractive Industries Transparency Initiative (EITI).

Multilateral institutions such as the World Bank Group 22 have provided funding to strengthen government capacity and mining frameworks in developing countries. In 2012, IFC provided \$223.5 million in new mining investments,

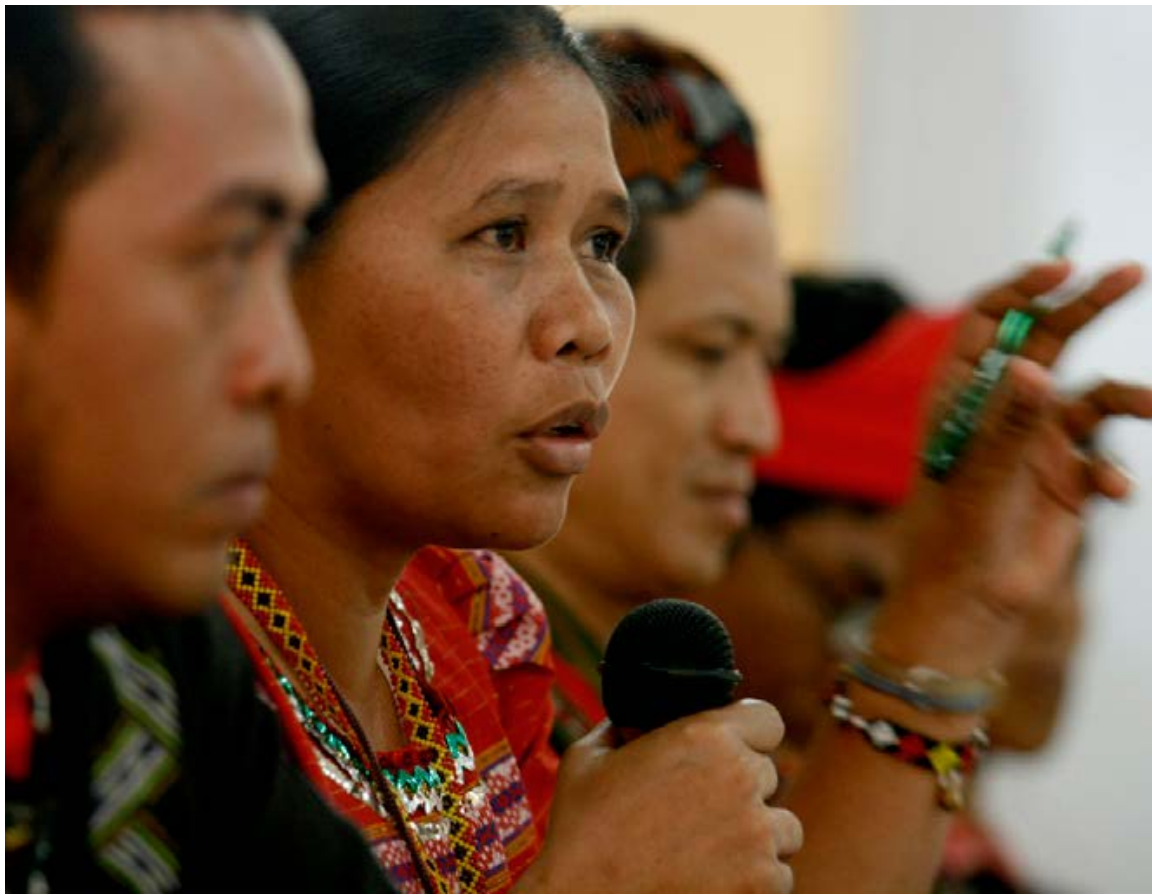

Norma Capuyan of ASLPC (an alliance of indigenous groups), photo by Keith Bacongco on Flickr while the International Bank for Reconstruction and Development and the International Development Association provided \$28.16 million to 16 countries for capacity-building initiatives on sector governance, transparency, support for the EITI, and artisanal mining. ${ }^{23}$ The International Monetary Fund has provided technical assistance to governments on tax administration and revenue management. It has also established a Managing Natural Resource Wealth Topical Trust Fund to support capacity development in 50 countries. ${ }^{24}$

Several initiatives have also provided templates for cross-country application, such as the Model Mine Development Agreement developed by the Mining Law Committee of the International Bar Association as a tool for governments. ${ }^{25} \mathrm{~A}$ recent study also identified 16 additional entities that provide such support, including the United Nations Development Programme (UNDP), the World Bank, the International Development Law Program, and the International Institute for Environment and Development. ${ }^{26}$

\subsection{THE ROLE OF COMMUNITY AGREEMENTS}

Community agreements are not new to the mining sector. There is a growing body of literature around these, including the World Bank's Model Regulations and Example Guidelines and Mining Community Development Agreements Source Book. While technical support for communities may be available from governments and civil society organizations (CSOs), there is little focus on independent legal representation for communities or on expanding funding sources for the community development agreement process.

Jurisdictions refer to these agreements in different ways, including community development agreements, participation agreements, impact benefit agreements, or indigenous land-use agreements. However denominated, these are formal, legally binding contracts between a mining company and affected communities. Governments are typically observers or witnesses, although they may be parties in certain jurisdictions, such as Papua New Guinea. 
Community agreements generally describe the project impacts, the rights and responsibilities of the parties, and their benefit-sharing arrangements. These agreements are used principally in the context of indigenous communities, although these may apply to nonindigenous local communities as well.

Certain jurisdictions require the negotiation and execution of community agreements, including the Philippines, Sierra Leone, South Sudan, and Afghanistan. The Democratic Republic of Congo and Guinea are considering them. While such agreements are not required in Canada, they are common, given the duty to consult with Aboriginals affected by projects on or near their traditional lands. There were more than 180 such community agreements documented by Natural Resources Canada as of $2012 .{ }^{27}$

While they may not be consistently required across countries, community agreements are encouraged by multilateral financing institutions, such as the World Bank, and by CSOs. The value of these agreements for companies is that they can facilitate consultations, demonstrate community support, and help assure project stability by reducing uncertainty and delays. For communities, they can demonstrate recognition and respect for their rights, incorporate social and environmental safeguards, and facilitate socioeconomic benefits such as employment and funds for community needs.

\section{By virtue of their right to self-determination, indigenous peoples are free to enter into negotiations directly with companies if they so wish. Indeed, direct negotiations between companies and indigenous peoples may be the most efficient and desirable way of arriving at agreed-upon arrangements for extraction of natural resources within indigenous territories that are fully respectful of indigenous peoples' rights, and they may provide indigenous peoples opportunities to pursue their own development priorities. ${ }^{28}$}

In addition to benefit-sharing arrangements, the process of negotiating, executing, and monitoring these agreements, in and by themselves, would embody capacity-building elements for communities. In this paradigm, communities are neither victims to external decisions nor passive recipients of benefits; they are equal partners in a relationship of trust.

Effective and equitable community agreements are possible only through thorough and informed negotiations between companies and communities. These include a consideration of impacts that should be addressed in a comprehensive social and environmental assessment, including negative impacts on traditional economies, health, competing resource-based activities, water use, land access, and air quality.

\subsection{COMMUNITY AGREEMENT CAVEATS}

Community agreements are challenging to develop, given the potentially long life of a mine, the possible changes in parties, operationspecific aspects, and community-specific conditions. Employment quotas, for example, are often qualified by the availability of certain skills in the local population; similarly, preferential contracting provisions are often qualified by cost-competitiveness. While these are intended to serve as socioeconomic safeguards, they may be rendered meaningless if community members lack the requisite skills to be hired. It is essential that community agreements incorporate sustained and context-specific capacity-building components.

There are also challenges in balancing transparency with confidentiality clauses protecting proprietary or sensitive financial information. Some companies and communities support the confidentiality of benefit allocation provisions as well, concerned that public knowledge will cause intra- or inter-community conflicts. While these are legitimate considerations, transparency is key to empowering communities to learn and benefit from these agreements. Under initiatives like the EITI, there is increasing pressure to publicize mining-related agreements. Public access to these agreements will facilitate evaluation and multi-stakeholder monitoring.

While there should be stability in terms of engagement, obligations, and responsibilities, there should also be flexibility built-in to adjust to changing circumstances and lessons learned. The principal caveat is that the agreement is not an end unto itself, but rather should be a reflection of a continuing, dynamic relationship. Ultimately, the strength of a community agreement, as with most agreements, lies in the quality of engagement between the parties. 


\title{
3.3 SUPPORTING COMMUNITIES IN THE NEGOTIATION OF AGREEMENTS
}

A multi-stakeholder meeting focused on mining issues noted:

\begin{abstract}
Sustained capacity-building on the community side will be necessary for such engagement, and the mechanisms through which such activities can be funded on a sustained basis present a key challenge. For example, it is necessary to find appropriate ways to provide independent and competent legal advice to affected local communities. ${ }^{29}$ (Emphasis added)
\end{abstract}

Therein lies a major gap in community capacity and engagement in the mining sector. There is limited funding to directly support communities in the capacities and tools they need in order to negotiate specific agreements. The negotiation of community agreements entails costs that should be internalized and borne by the project. A company will typically have its own internal legal team and even outside counsel to negotiate an agreement. Communities, on the other hand, are often at a disadvantage given their unfamiliarity with mining, limited awareness of their rights, and lack of financial resources to represent themselves and to hire outside experts.

With this imbalance in experience and negotiating skills, social issues and conflicts can arise in part because communities are not adequately or independently represented in negotiations. Communities "must have the ability to negotiate on fair terms with government and private companies...[and] must be able to benefit equitably from extractive processes." ${ }^{\prime 30}$ Given that communities would not typically have the independent financial means to advance the costs of legal representation and negotiations, a central challenge is how to obtain funds up front to support them in this process.

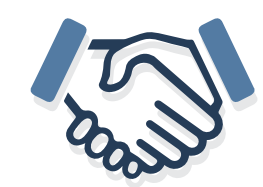

\section{FUNDING SUPPORT OPPORTUNITIES FOR C O M M U I T I S IN NEGOTIATION AGREEMENTS}

\section{- Public Funding}

Significant institutional resources from the World Bank, the UN, and other international organizations have been allocated for extractive sectors, principally for governance issues related to mining and oil and gas. These resources are generally directed to governments to support legal reforms and the improved capacity to combat corruption and to strengthen enforcement. ${ }^{31}$ Public funding is limited, however, and vulnerable to global factors. Official development assistance has declined, likely due, in part, to the last global recession and the austerity measures undertaken by various countries as numerous priorities compete for limited domestic resources.

While communities in multi-stakeholder initiatives can be directly involved or represented through $\mathrm{CSO},{ }^{32}$ institutional public resources are rarely provided directly to communities. This may be understandable where community structures are unclear or where communities lack systems to receive financial assistance. Even when communities are more organized and financially capable, lack of access to credit or financing from traditional lending institutions remains a barrier.

\section{Mining Company Funding}

Mining companies increasingly allocate budgets and staff for community relations, although lower commodity prices have led to significant reductions in such expenditures. Companies may hire or partner with other institutions whose core business is community engagement. Larger companies may create foundations through which they undertake community development initiatives. It will likely constitute a conflict of interest, however, for a company to directly fund the hiring of legal advisors and related costs for local communities with whom they seek to negotiate an agreement. Principles of informed decision-making and self-determination would dictate that a community should have advisors who will zealously advocate for their clients' interests, and who in no way can be seen as being beholden to the company or the government.

\section{- Civil Society Support}

Many CSOs provide support for governments and community representatives related to mining sector governance, including the Natural Resource Governance Institute, ${ }^{33}$ Oxfam, the International Senior Lawyers Project, the World Resources 
Institute, the Center for International Forestry Research, Resources for the Future, and Conservation International. Such organizations generally rely on philanthropic or private foundations, international organizations, and government funding. Few strategic efforts appear to be dedicated specifically to funding negotiation processes for communities and projects.

\section{Social Impact- and Program-Related Investments}

"Impact investing" refers to investment efforts that generate measurable social benefits in addition to financial returns. ${ }^{34}$ It "actively seeks to place capital in businesses and funds that can provide solutions at a scale that purely philanthropic interventions usually cannot reach." ${ }^{35}$ The Monitor Institute estimated that impact investments, such as microfinance and clean technology investments, could grow from an estimated $\$ 50$ billion in assets in 2009 to $\$ 500$ billion by $2020 .{ }^{36}$

Program-related investments (PRIs) ${ }^{37}$ made by US foundations, also called below-market mission investments, are social impact investments in entities or projects aligned with their missions. They further a private foundation's tax-exempt purposes while pursuing modest financial returns, although PRIs are not principally intended to generate profit. PRIs are most commonly made in the form of loans or equity investments, although they also include other instruments, such as lines of credit, loan guarantees, interim financing, mortgage financing, linked deposits, and business start-up capital. ${ }^{38}$

PRIs have existed in the US since the 1960s, and their use was pioneered by the Ford Foundation, which in 2011 committed $\$ 560$ million for this purpose, and which sets aside an average of \$25 million annually for new investments. ${ }^{39}$ Traditional examples of PRIs include low- or no-interest loans to disadvantaged students or small businesses and high-risk investments in affordable housing. ${ }^{40}$ Other innovations can be seen in the W.K. Kellogg Foundation's earmarking of \$75 million in 2007 for enterprises that provide nutritious food to at-risk children and their communities, while in 2011, the Bill \& Melinda Gates Foundation acquired a $\$ 10$ million equity stake in a for-profit biotechnology company to ensure better delivery of vaccines to the poor in Africa and elsewhere. ${ }^{41}$ While PRIs and impact investments are more limited in natural resources sectors, micro and medium lending to small farmers have both produced positive results in developing regions of the world. ${ }^{42}$

PRIs have been used by less than $1 \%$ of US foundations, likely due to lack of information, limited expertise in PRI management, and lack of appropriate opportunities ${ }^{43}$ Their use has increased in recent decades, however, with over 400 such investments amounting to more than $\$ 400$ million by the mid-2ooos, compared to fewer than 200 PRIs valued at around $\$ 106$ million made in the mid-1990s ${ }^{44}$ There is growing interest among foundations in learning about and using PRIs, motivated by an interest in increasing resources for future use, maximizing social impact beyond grant-making, and developing the organizational capacity of recipients. ${ }^{45}$

The funding potential of PRIs is considered far greater than that of traditional grants. More than 76,000 US foundations paid out an estimated $\$ 46.9$ billion in grants in 2011, as compared to about $\$ 646.1$ billion in assets. ${ }^{46}$ In addition to greater amounts of funding being available through PRIs, they are especially advantageous for high-risk projects or borrowers.

Given the unavailability of funding from either public or traditional private sources for the capacity and negotiation needs of communities dealing with mining, there is a tremendous and novel opportunity for PRIs and social impact investments to fill that gap and catalyze positive social change in the form of strengthened community capacity and more equitable community agreements that will help address conflict while maximizing local benefits.

This is a challenging concept, as PRIs and impact investments do not appear to have previously been directed toward supporting the provision of legal services and associated costs for negotiating a community agreement in a mining project. Part IV will thus examine country conditions to identify those that may facilitate the entry of social impact investments as a vehicle to support the capacity-building and negotiation costs of a community.

The key challenge presented in this paper is whether social impact investments can provide a funding mechanism that communities can use to obtain independent and competent legal services and negotiate effective community agreements. This calls for a consideration of country-specific conditions relevant to mining governance. 


\section{IMPACT INVESTMENTS TO SUPPORT THE NEGOTIATION OF COMMUNITY AGREEMENTS: MINING GOVERNANCE AND THE PHILIPPINES CASE STUDY}

\subsection{AN OVERVIEW OF SELECT MINING GOVERNANCE JURISDICTIONS}

Mining governance frameworks in select developing countries from diverse regions were reviewed; Guatemala in Central America, Ghana in West Africa, Papua New Guinea (PNG) in Oceania, and the Philippines in Southeast Asia. These countries are relatively young democracies; PNG gained independence in 1975 after 70 years of Australian administration; military-backed regimes ended in the Philippines and Ghana in 1986 and 1992, respectively; and the end in 1996 of three and a half decades of civil war in Guatemala marked their return to a representative form of government.

These countries' constitutions and national development plans emphasize economic growth and principles of sustainable development. These include the promotion of public participation and EIAs for development projects, as generally required under their cross-cutting environmental laws.

Each of these countries is culturally diverse, home to a multiplicity of ethnolinguistic groups. ${ }^{47}$ Communities in remote rural areas rely principally on resource-based activities such as fishing. About $30 \%$ of Filipinos, $40-50 \%$ of Ghanaians, and over $60 \%$ of Guatemalans depend on agriculture. ${ }^{48}$ More than $80 \%$ of PNG's population lives in rural areas and engages in subsistence farming. ${ }^{49}$

Land tenure in Ghana and PNG is largely held under customary law, with such lands in PNG encompassing an estimated 97\% of the country's area..$^{50}$ Guatemala has neither a basic land law nor mechanisms to recognize customary tenure. In contrast, the Philippines has a longstanding system of ownership under civil law, and a more recent framework on native title. Across these four countries, however, the insecurity of customary land tenure remains a common and serious challenge.

Important biodiversity resources are found in these countries, most notably in the Philippines and Guatemala. At the same time, they hold vast mineral and other natural resources. While estimates are difficult to obtain, there are likely thousands of small-scale mining groups across these countries. There have typically been few legislative measures to address small-scale mining issues, and governments have tended to focus on large-scale mining. These countries enacted new mining laws beginning in the 1990 s in order to attract greater investments. ${ }^{51}$ They generally provide the modes and scope of mining rights, obligations of mining proponents, fiscal provisions, and other legal requirements. Later issuances, such as Ghana's Mining Law of 2006, involved greater participation by stakeholders from civil society, labor unions, and local governments. ${ }^{52}$ The countries vary in policies regarding other mining-related issuances, with some enacting sector-specific environmental regulations and laws on small-scale mining, and others imposing mining royalties or an additional profits tax.

These countries have attracted new and large mineral investments, from the traditional multinationals based in the West to newer investors from emerging economies. Eightyfive percent of Ghana's mining industry is reportedly held by foreigners, with the remainder owned by the state. ${ }^{53}$ Foreign companies also have substantial mining investments and projects in the Philippines, Guatemala, and PNG. Ghana is Africa's second-largest gold producer, with gold constituting over $90 \%$ of the country's total mineral exports. ${ }^{54}$ PNG was the world's twelfth-largest gold producer in 2013,55 and its mineral resources account for over two-thirds of export earnings ${ }^{56}$ and one-third of tax revenues. Mining revenue in Guatemala reached \$993.9 million in 2013,57 and the government anticipates more than $\$ 3.8$ billion in mineral investments by the end of $2015 .^{58}$

Despite these macroeconomic gains, income inequality and poverty persist in these countries (See Table 1). More

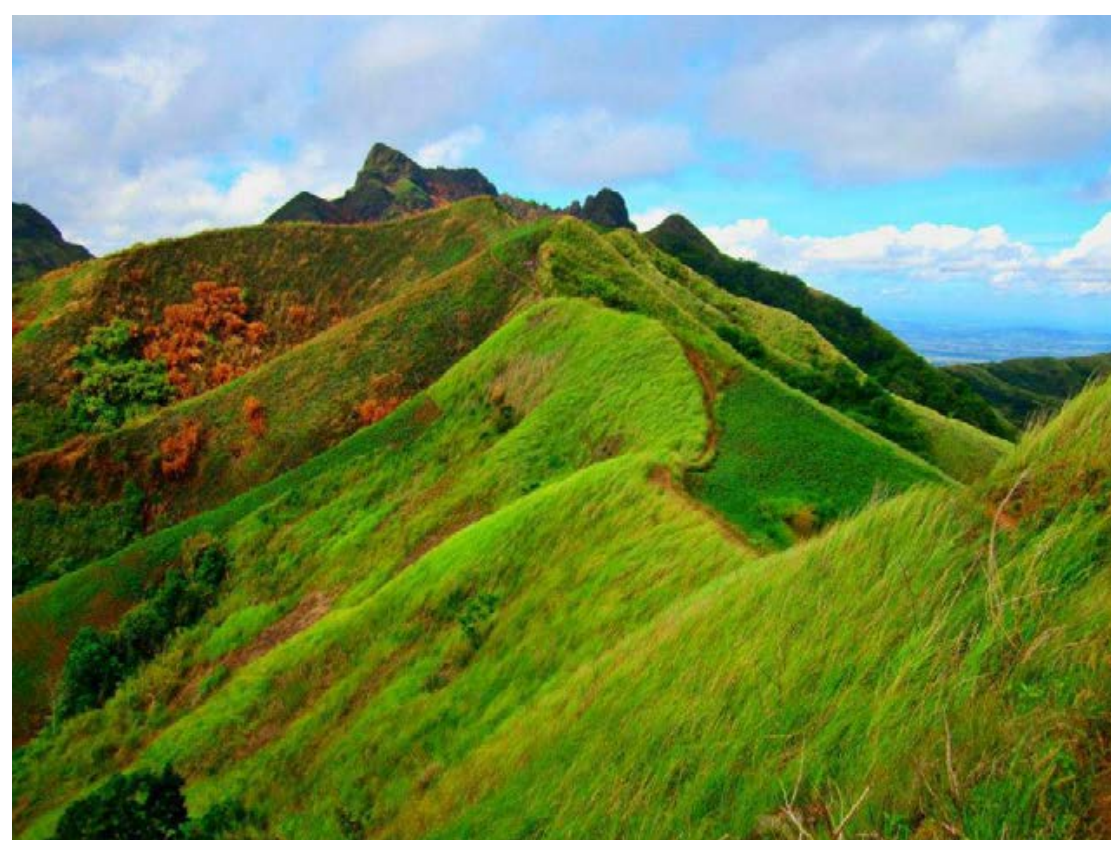

Mt Batulao, photo by Chie 
than one-quarter of the populations of Ghana, PNG, and the Philippines live below the poverty line. The contrast is even greater in Guatemala, where over half of the population remains impoverished despite modest growth.

\section{TABLE 1}

\begin{tabular}{|c|c|c|c|c|}
\hline POPULATION & 26 million & 15.83 million & 7.321 million & 100.6 million \\
\hline LAND AREA (SQ.KM.) & 239,460 & 108,889 & 462,840 & 300,000 \\
\hline GDP GROWTH & $7.7 \%$ & $3.5 \%$ & $8 \%$ & $6.1 \%$ \\
\hline POVERTY RATE & $24.2 \%$ & $54 \%$ & $28 \%$ & $25.8 \%$ \\
\hline $\begin{array}{l}\text { CORRUPTION } \\
\text { PERCEPTIONS INDEX } \\
\text { (RANK/SCORE) }\end{array}$ & $61^{\text {st }}(48)$ & $115^{\text {th }}(32)$ & $145^{\text {th }}(25)$ & $85^{\text {th }}(38)$ \\
\hline $\begin{array}{l}\text { FRAGILE STATES INDEX - } \\
\text { WARNING }\end{array}$ & High (108) & Very High (80.3) & Very High (84.1) & Very High (85.3) \\
\hline
\end{tabular}

Sources: UNDP, UN Data, World Population Review, Food and Agriculture Organization, African Economic Outlook, Ghana High Commission, World Bank, Asian Development Bank, Philippine Statistics Authority, Corruptions Perceptions Index, Fragile States Index.

Poor communities relying on subsistence and resource-based activities are especially vulnerable to the effects of major mining projects that entail large-scale land use. Moreover, where resource wealth exists amid poverty, corruption and conflict are all too common. All four countries are perceived as having serious corruption issues, based on their low scores (out of 100) on the Corruption Perceptions Index that ranks 176 countries. ${ }^{59}$ Similarly, they fare very poorly on the Fragile States Index. ${ }^{60}$ While Ghana has a "High" warning for fragility due to human flight and weak public services, the others had "Very High" warnings, with concerns in Guatemala and PNG over demographic pressures, uneven economic development, and other factors. The Philippines stands out not only for its disproportionately large population and demographic pressures, but also for being among the "most-worsened" countries in 2014 due, among others, to internal conflicts, corruption, security issues, and factionalized elites.

\subsection{CHALLENGES TO GOOD GOVERNANCE}

Mining policies have been developed recently in the Philippines, PNG, and Ghana that emphasize not only economic goals but sustainable development in the management of mineral resources. These include environmental protection, community engagement, and public participation. Various measures have been taken by the governments in these countries to help address conflict, social exclusion, revenue allocation, and corruption issues related to mining.

Ghanaian authorities are required to notify landholders in writing before a license for mining is granted on their land. ${ }^{61}$ PNG law appears to go further than notification by requiring the government to secure the landowners' agreement. Beyond landowners, the Mines Minister in PNG is required to convene a forum before granting any special mining lease in order to consider the views of those who will be affected. ${ }^{62}$ Similarly, the mining and environmental laws in Guatemala and the Philippines provide citizens with the opportunity to express their opposition to any mining activities.

While these laws support equal rights and consultations around development decisions, public participation-particularly by women and other historically marginalized sectors-remains very limited. Lack of information, capacity, and access to formal legal procedures are often barriers for rural communities to voicing their concerns or complaints.

In 1996, Guatemala ratified ILO 169, which sets forth situations requiring FPIC, but the convention remains unenforced due to the lack of implementing regulations. Under their Municipal Code, indigenous communities may submit requests for consultation to the Municipal Council. Non-indigenous communities may do so as well, provided the request is signed by at least $10 \%$ of the municipality's registered residents. There is some confusion and controversy, however, over the voting procedures surrounding such a consultation, its legal status, and whether its results are binding. ${ }^{63}$

All four countries are members of the EITI that aims to combat corruption, improve accountability, and facilitate good governance by requiring the publication and reconciliation of payments by extractive companies and receipts by governments. Equally notable, such a process requires public participation and dialogue as it is implemented in each country by a multi-stakeholder group consisting of government authorities and representatives of companies and CSOs. 
Back to Table of Contents

International organizations such as the World Bank and the UNDP work with and through governments to fund a range of initiatives relevant to mining, including peace-building and public participation activities. ${ }^{64}$ There are also CSOs in these countries that are actively involved in causes relevant to extractive industries. CSOs may provide technical assistance; for example, the non-profit Centre for Indigenous Knowledge and Organizational Development and the Wassa Association of Communities Affected by Mining support the negotiation of community agreements in Ghana.

Larger mining companies typically allocate budgets for corporate social responsibility programs, which may be voluntary or legally mandated, as is the case in the Philippines. In Ghana, mining companies have funded community programs to support local infrastructure, livelihoods, and the development of small businesses. ${ }^{65}$ They committed \$26 million in 2012 to support local sustainable development plans. ${ }^{66}$ Neither international organizations nor CSOs and companies appear to provide sustained funding to support community negotiations with companies and governments over mining projects.

PNG's Sovereign Wealth Fund and Ghana's Mineral Development Fund were established to capture a portion of mining revenue in order to sustainably manage it for socioeconomic and community development programs, while protecting against commodity price volatility. Guatemala is considering the establishment of a similar fund that would distribute a percentage of royalties not only to government agencies but to affected local communities. ${ }^{67}$ While significant, these funds are not typically structured to support specific communities wishing to negotiate agreements with mining companies and build capacity to manage mining revenues sustainably.

The Philippines was selected specifically for more detailed examination given that its legal framework explicitly requires FPIC, community agreements, and payment of royalties for mining projects. Agreements are also required for social programs benefitting local communities, both indigenous and non-indigenous. While the country has had almost 20 years of experience dealing with the FPIC requirements, the capacity of indigenous communities to engage with mining companies generally remains very limited, and the mining sector there remains plagued by conflicts arising from militarization around project areas, insurgent groups, displacement, corruption, equity issues in revenue sharing, and a host of environmental impacts.

\subsection{PHILIPPINE CONDITIONS AND THE MINING DILEMMA ${ }^{68}$}

The Philippines has a total area of 300,000 square kilometers ${ }^{69}$ with mountainous terrain, forests, and extensive coastal lowlands. It is one of 18 megadiverse countries that together comprise more than two-thirds of the world's biological wealth. More than half of the population of over 100 million $^{70}$ lives in coastal areas, and more than a third depend on agriculture and fisheries for their livelihoods.

The country has had positive economic gains in recent years, including 6.9\% GDP growth in the last quarter of 2014, which is among the strongest in the Association of Southeast Asian Nations. Life expectancy is about 68 years for males and 73 for females, the simple literacy rate is an impressive $95.6 \%$ (2008), and the elementary enrollment rate is at $90 \%$, with a rate of $61 \%$ for secondary education. Despite these indicators, allegations of systemic corruption dominate the national news while poverty affects at least a quarter of the population, reaching up to two-thirds in some rural areas. ${ }^{71}$

Armed anti-state groups persist in the country-the New People's Army (NPA), the military wing of the Communist Party, was formed in 1969 and is reportedly active in 69 out of the country's 81 provinces. ${ }^{72}$ Estimates of their membership numbers vary from 5,000 to as high as 10,000 , and the insurgency has reportedly resulted in over 40,000 casualties. ${ }^{73}$ The Moro Islamic Liberation Front, the largest Muslim separatist group, signed a peace agreement with the government in 2014 that calls for the establishment of a new Bangsamoro political entity that would grant Muslim self-rule in the southernmost part of Mindanao. The bill creating the region is pending. ${ }^{74}$

Mining operations, especially those involving foreign companies, have long been targeted by insurgent groups. The NPA reportedly raised almost one billion pesos in "revolutionary taxes" in $2008 .{ }^{75}$ The group attacked at least five mining company facilities in 2014. Tension has also

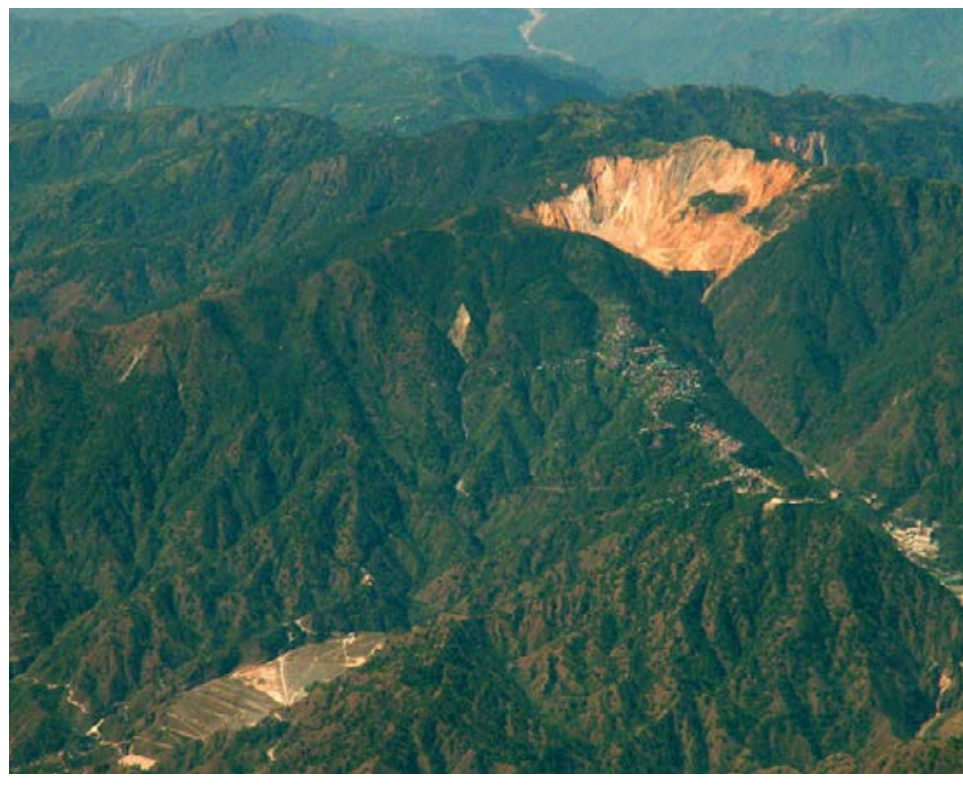

Philex open pit mine, photo by StormCrypt on Flickr 
resulted from the heightened presence of government and paramilitary forces protecting mining areas. This can cause deep resentment within local communities, potentially providing a recruitment opportunity for insurgent groups. The militarized environment and conflicts have led sporadically to deaths of activists opposed to mining and some mining company personnel.

The mountainous and forested areas in the northern and southern Philippines not only host many major mining deposits, they also provide the ideal terrain from which to carry out guerrilla operations. ${ }^{76}$ For this and a host of complex reasons, the mining sector has long presented a development dilemma for the Philippines. On the one hand, the country undoubtedly possesses a wealth of mineral reserves reportedly worth almost US\$1.4 trillion across nine million hectares $(\mathrm{Ha}) .{ }^{77}$ Mineral reserves are estimated to be about 14.5 billion tons of metallic minerals and 67.6 billion tons of nonmetallic minerals. The country is the leading producer of nickel, and its deposits rank third globally in gold; fourth in copper; fifth in nickel; and sixth in chromite.

On the other hand, further investments would add even more pressure in areas already affected by conflict and stressed by biodiversity loss, multiple land uses, and the growing population. While mining tenements currently cover about $420,000 \mathrm{Ha}$, or just $1.4 \%$ of the country's land mass, these are typically situated in remote rural areas inhabited by poor communities where inhabitants have had little to no participation in project decisions and benefits. About $60 \%$ of mining operations in the Philippines reportedly take place within ancestral domains of indigenous communities. ${ }^{78}$

For indigenous as well as non-indigenous communities, most of whom rely on subsistence agriculture and fishing, land use for mining often entails socioeconomic displacement due to the loss of access to these resources. It almost certainly would also entail physical displacement from the loss of homes and villages and the relocation of communities to make way for mining operations and facilities. Whether and to what extent mining is allowed, under what conditions and for whose benefit - these are among the challenges that the country has grappled with for decades, as reflected in key policy and legal measures.

\subsection{MINING SECTOR GOVERNANCE}

The Philippines' natural resources are owned by the state, and the large-scale development of mineral resources is principally governed by the Philippine Mining Act of 1995 (Republic Act No. 7942). Other laws and government agencies are also relevant, particularly when dealing with revenue sharing, environmental issues, and community concerns.

The Mines and Geosciences Bureau (MGB) under the Department of Environment and Natural Resources (DENR) is principally responsible for implementing the Mining Act and its regulations. The DENR's Environmental Management Bureau administers the Philippine Environmental Impact Statement System, under which mining projects are required to undergo an EIA and secure an environmental compliance certificate as a condition for project commencement. The Board of Investments administers the granting of incentives for mining investors, while the Philippine Ports Authority regulates the transport of mining-related equipment and ore.

The National Commission on Indigenous Peoples (NCIP) is tasked with implementing the Indigenous Peoples Rights Act (IPRA) while Local Government Units (LGUs) exercise local autonomy, under the general supervision of the president, over provinces, municipalities, cities, and barangay (local villages).

\section{LEGISLATION \& AGREEMENTS FO R THE PHILIP P I N E MINING SECTOR}

\section{Mining Rights and Revenues}

The state may grant exploration permits and it may enter into co-production, joint venture, or Mineral Production Sharing Agreements (MPSA) with Filipino citizens or corporations. ${ }^{79}$ The Constitution and Mining Act carved out an exception to this nationalist approach to natural resources development by allowing the president to enter into Financial and Technical Assistance Agreements (FTAAs) with fully foreign-owned corporations involving large-scale investments. The areas applied for range from $32,400 \mathrm{Ha}$ onshore for exploration permits to $81,000 \mathrm{Ha}$ onshore for FTAAs. After compliance with relinquishment requirements, the final mining area for mineral agreements and FTAAs shall be no more than 5,000 $\mathrm{Ha}$. 
Back to Table of Contents

Community Agreements and Mining: A New Frontier for Social Impact Investments | 15

As of October 2015, there were 31 exploration permits covering about 109,193 Ha, 338 MPSAs over 583,809 $\mathrm{Ha}$, and six FTAAs over $108,872 \mathrm{Ha}{ }^{80}$ Of the 37 MPSAs and one FTAA currently in production, more than half are located in the southern island of Mindanao, while over a third are found in the northern island of Luzon. The NPA is active in these regions, and particularly in areas near or around mining operations.

Collections made by the national government from mining projects include income and excise taxes, value-added tax, customs duties, royalties from mineral reservations, mine waste and tailings fees, documentary stamp tax, capital gains tax, and a tax on branch profit remittances. LGUs collect other taxes and fees as well. Royalties for indigenous communities are also required for operations within ancestral domains or lands.

Principal incentives for mining investors include zero-duty importation of capital equipment, spare parts, and accessories. ${ }^{81}$ FTAA contractors are also allowed to recover their pre-operating expenses before they pay the required government share. This cost-recovery period ends five years from the commencement date of commercial production or when net cash flows are equal to pre-operating costs, whichever occurs earlier. In exceptional cases involving larger investments, the investor and the DENR may negotiate a longer cost-recovery period.

Due to the relatively small number of producing mines combined with lower commodity prices, economic figures appear underwhelming. Mining's contribution relative to total government tax income was only $1.12 \%$ in $2012 .{ }^{82}$ According to 2014 statistics from the MGB, ${ }^{83}$ the mining sector directly employed just 235,000 or $0.6 \%$ of the workforce of about 39 million, although figures for indirect employment and associated economic benefits are unavailable. While metallic minerals constituted about $6.5 \%$ of exports, behind manufacturing and agricultural products, the sector accounted for only $0.7 \%$ of GDP.

In 2012, Philippine President Benigno Aquino issued Executive Order No. 79 (EO 79), ${ }^{84}$ which defined additional "no-go zones," such as prime agricultural lands, ecotourism sites, and other protected areas, where mining is prohibited. The order aims to "improve environmental mining standards and increase revenues to promote sustainable economic development and social growth." It established the Mining Industry Coordinating Council (MICC) and imposed a moratorium on new mining agreements until Congress revises the revenue-sharing structure. EO 79 notwithstanding, the area of community engagement is viewed as needing further enhancement. ${ }^{85}$

A number of relevant bills are currently pending in Congress, including proposals to create an independent health and

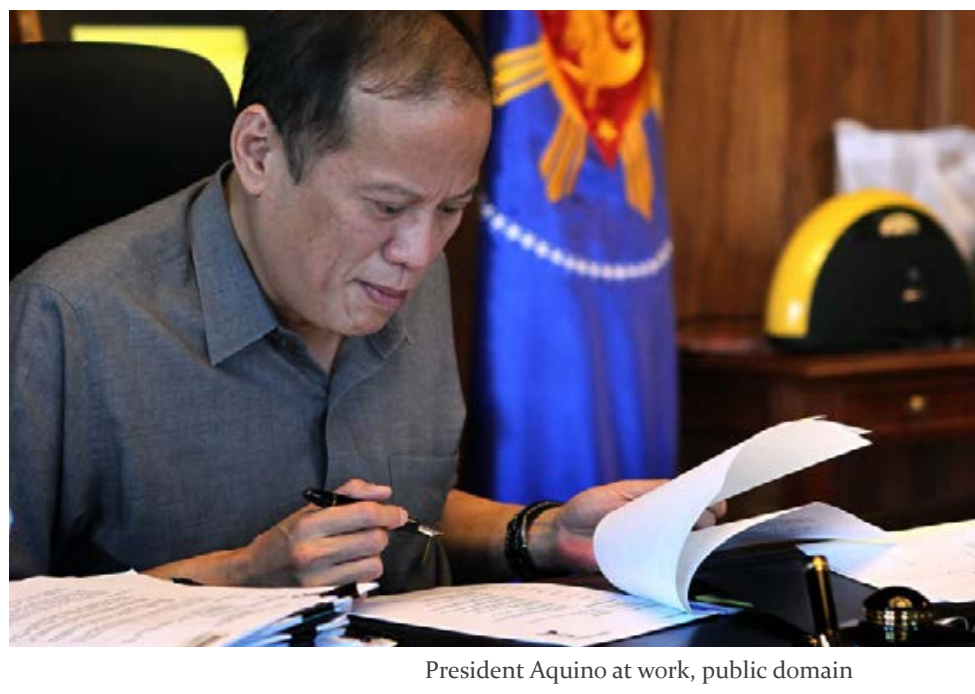
environmental assessment for mining projects and ensure equitable sharing of benefits among the government, indigenous peoples, and local communities. The MICC also submitted a proposal to the president for approval and submission to Congress. This would impose the higher of either a $10 \%$ tax on gross revenue or a $45-55 \%$ share of adjusted mining revenues, in addition to a share in windfall profits.

At the same time, the constitutionality of the Mining Act is once again before the Supreme Court. The Court previously upheld the law's validity in 2005 after prolonged litigation. The pending case challenges whether mining agreements result in an equitable sharing of wealth.

\section{Revenue Allocation: National and Local Governments}

Pursuant to the Local Government Code, LGUs have key responsibilities devolved from the national government, including some in infrastructure, health services, environmental management, agriculture and fisheries, tourism, and artisanal and small-scale mining. The LGU is a member of the Provincial or City Mining and Regulatory Board that determines small-scale mining areas and administers artisanal and small-scale mining. This board also receives applications for quarry permits. All mining projects require consultation with the concerned LGUs and approval from the appropriate Sanggunian (local legislative body). 
The Internal Revenue Allotment for all LGUs is $40 \%$ of national taxes. This is further allocated among the different units based on population and land area. At least $20 \%$ of this allocation is intended for development plans approved by local development councils. With respect to mineral development, LGUs receive $40 \%$ of the gross collections from mining taxes, royalties from mineral reservations, and other fees generated through mining agreements. This is remitted to LGUs based on where mining operations are situated, and is intended to fund local development and livelihood projects. In addition, LGUs collect business taxes, real property taxes, community taxes, occupation fees on onshore mining operations, and regulatory fees to enforce environmental and other requirements.

Challenges persist with the lack of efficiency and transparency in the transfer of funds from the national treasury to LGUs, and from LGUs to community-based services and benefits. The law requires that excise taxes and royalties shall finance local development and livelihood projects, but various respondents consulted in the Philippines report that some LGUs use them for operating expenses and other projects.

\section{Mining in Ancestral Domains and Lands: Free Prior and Informed Consent and Memoranda of Agreement}

The IPRA ${ }^{86}$ affects the 110 ethnolinguistic groups in the country, as it recognizes indigenous rights of ownership and possession over ancestral domains and lands. ${ }^{87}$ Distinct from the civil or common law concept of property rights, the IPRA defines indigenous ownership as the rights of indigenous peoples to sustainably use, manage, protect, and conserve the land, resources, and sites within their ancestral domains and lands in accordance with their knowledge, beliefs, systems, and practices. These rights may be manifested in native title, specifically, through Certificates of Ancestral Domain Titles or Certificates of Ancestral Land Titles issued by the NCIP. ${ }^{88}$

Indigenous rights of ownership include the community's priority right to develop their natural resources. In this case, the community shall issue a resolution to that effect during an assembly. The community may engage a partner subject to their $\mathrm{FPIC}^{89}$ and execute a Memorandum of Agreement (MOA) to set forth the terms of their partnership.

The IPRA prohibits mining on the community's sacred grounds or other areas reserved by them for special purposes or as specifically identified in their Ancestral Domain Sustainable Development and Protection Plan (ADSDPP). ${ }^{90}$ Where it is not prohibited, the indigenous community's FPIC is a pre-condition for the grant or renewal of any government concession, and prior to a relocation proposed as an exceptional measure. ${ }^{91}$ Indigenous communities have the right to stop or suspend any project that has not undertaken the consultations required in complying with FPIC processes. ${ }^{92}$

If the community does not give its consent, a Resolution of Non-Consent shall be issued. If the community consents, a Resolution of Consent and MOA will be prepared that sets forth the parties' terms of engagement. The MOA should be in the language of the community and translated into English or Filipino. Under IPRA regulations, the NCIP provincial Legal Officer is responsible for drafting the MOA, which shall be read aloud at a community assembly for affirmation. Revisions will be made by the FPIC Team based on the assembly's instructions. The MOA should be signed within the ancestral domain by authorized representatives of the parties at that assembly.

NCIP Administrative Order No. 3 of 2012 provides that the MOA should include the following minimum requirements:

- $\quad$ Term of the agreement;

- $\quad$ Responsibilities of the parties;

- Detailed benefit-sharing provisions, including the legally required royalty payment to the community of not less than $1 \%$ of gross output; ${ }^{93}$

- Mitigation and resettlement plans;

- $\quad$ Detailed use of all funds to be received by the community;

- Monitoring of MOA implementation;

- Provisions in case of merger, reorganization, transfer of rights, acquisition by another entity, or joint venture; and

- $\quad$ Redress mechanisms, remedies, and penalties for non-compliance or violations. 
Back to Table of Contents

Community Agreements and Mining: A New Frontier for Social Impact Investments | 17

Royalties may be released through a Trustee Bank or directly to the account of a private, non-profit, voluntary indigenous peoples' organization authorized by the community and accredited by the NCIP. Fund disbursement requires the concurrence of the appropriate NCIP Commissioner and the NCIP Chair. These funds shall be managed and used in accordance with the Community Royalty Development Plan formulated by the community, taking into account their ADSDPP. The Community Royalty Development Plan requires confirmation by the NCIP Commission en banc, and must include allocations for livelihood and social development projects, education and training, capitalization for cooperative development, credit facilities, payments for professional services, and emergency concerns.

\section{Mining and Non-Indigenous Communities}

Under the Mining Act, companies must allocate $1.5 \%$ of their operating costs for Social Development Management Programs (SDMP), or for Community Development Programs in cases of exploration. Seventy-five percent of this shall be for the development of host and neighboring communities, $10 \%$ for the development of mining technology and geosciences, and $15 \%$ for information, education, and communication programs.

To develop the SDMP, the companies shall carry out a Social Impact Assessment and Participatory Rapid Appraisal to identify project impacts and evaluate community needs. Following this assessment, an SDMP is prepared in consultation with host and neighboring communities and other stakeholders. This is submitted to the MGB Regional Office for approval every five years.

The company is required to enter into a MOA with the host and neighboring communities within 30 days of the approval of the SDMP. The communities shall be represented by the appropriate barangays or municipalities. Activities for the development of host and neighboring communities include enterprise development, infrastructure development and support services, educational programs, and health services. These social expenditures may not be included in or charged against royalty payments for indigenous communities. Unspent amounts are carried forward to the following year.

The company's Community Relations Officer oversees implementation of the SDMP. The Community Relations Officer and authorized community representatives are responsible for regularly monitoring implementation of the SDMP. Failure by the company to implement its SDMP may be penalized by a fine of 5,000 pesos (about $\$ 114$ ) for the first offense, and its mining and milling operations may be suspended for a subsequent offense.

\subsection{IMPLEMENTATION ISSUES IN FPIC PROCESSES AND MOA NEGOTIATIONS}

The NCIP acknowledges the challenges in implementing FPIC processes, for example, in determining whether a community is genuinely informed and whether consensus has been achieved. ${ }^{94}$ Unanimity is rare, and the extent to which dissent represents a flawed process is often difficult to assess. Some CSOs have observed that information disseminated to communities typically consists of materials provided by companies, which can result in one-sided decision making. ${ }^{95}$

What FPIC means in practice and whether it necessarily results in a MOA are fundamental issues. "When the FPIC process is facilitated by the government, communities often believe that the project is a done deal and that they are left with no other option but to enter into a MOA for the project. The FPIC process should be understood as one where indigenous communities can exercise their right to say 'no;' it is not simply a long tedious process with a pre-determined result in favor of a project."96

In the case of non-indigenous communities, FPIC is not required. Decision-making in these cases is dominated by the LGU, making the concept of social acceptability nebulous. ${ }^{97}$ The report of the Philippine Extractive Industries Transparency Initiative reviewed SDMP information gathered for 2012 and found that these expenditures amounted to one billion pesos (roughly \$23 million), with some companies working through foundations while others funded projects identified by LGUs. ${ }^{98}$ MOAs with communities were not subjected to detailed monitoring or evaluation, however, and there has been no systematic assessment of the link between these social expenditures and positive impacts asserted.

The same holds true for FPIC processes and MOAs with indigenous communities. As of December 31, 2010, 309 compliance certificates had been issued by the NCIP for projects in which FPIC processes had been completed and consent obtained from communities. Over half of these were for exploration and mining projects. Of the 39 operating metallic mines in the country, 28 were within ancestral areas. ${ }^{99}$ 
Back to Table of Contents

\subsection{THE CASE FOR SOCIAL IMPACT INVESTMENTS}

Various laws and regulations govern the Philippine mining sector and address economic, environmental, and social issues. Democratic institutions are likewise established, despite concerns regarding capacity, efficiency, and transparency. The MGB and NCIP have been implementing the Mining Act and IPRA, respectively, for close to two decades. The mining sector increasingly recognizes the importance of sustainability issues, and is active in multi-stakeholder initiatives such as the EITI. CSOs and academic institutions are similarly engaged, advocating various reforms and representing a broad spectrum of positions that contribute to public debate on the socioeconomic and environmental issues related to mining.

The Mining Act and the IPRA contain a number of socioeconomic and environmental safeguards consistent with sustainable development principles, including the EIA and SDMP requirements for mining projects. The effectiveness of these safeguards is hampered, however, by legal and enforcement challenges:

- The Mining Act and the IPRA represent distinct, though parallel, systems of resource ownership. While these might be conceptually compatible, the application of both systems in a specific area has contributed to insecurity of title, disputes over mining rights and priority rights, and even to violent conflicts over land and resources.

- Customary rights over ancestral domains and lands that have not yet been delineated or covered by a Certificate of Ancestral Domain Title or Certificate of Ancestral Land Title are often even more unclear, rendering these particularly vulnerable to elite capture and usurpation.

- A dilemma arises when a community has not yet had the opportunity to exercise their right to self-determination, as articulated, for example, through their ADSDPP; the community would be pressured to evaluate a particular project without the benefit of considering broader goals and other development options. ${ }^{106}$

- Detailed information on community benefits and benefit allocation is often limited. Indigenous communities encounter difficulties with mining and other resource-based projects, particularly in obtaining maximum benefits from these investments when they do not even have access to information on project revenues. ${ }^{107}$ Moreover, the sharing of mine revenues between national and local governments is often unclear.

Additionally, there is limited knowledge and understanding among communities around mining operations. This adversely impacts their capacity to assert their rights and interests, negotiate equitable agreements on terms that maximize community benefits, monitor compliance with agreed-upon responsibilities, and sustainably manage mine revenues.

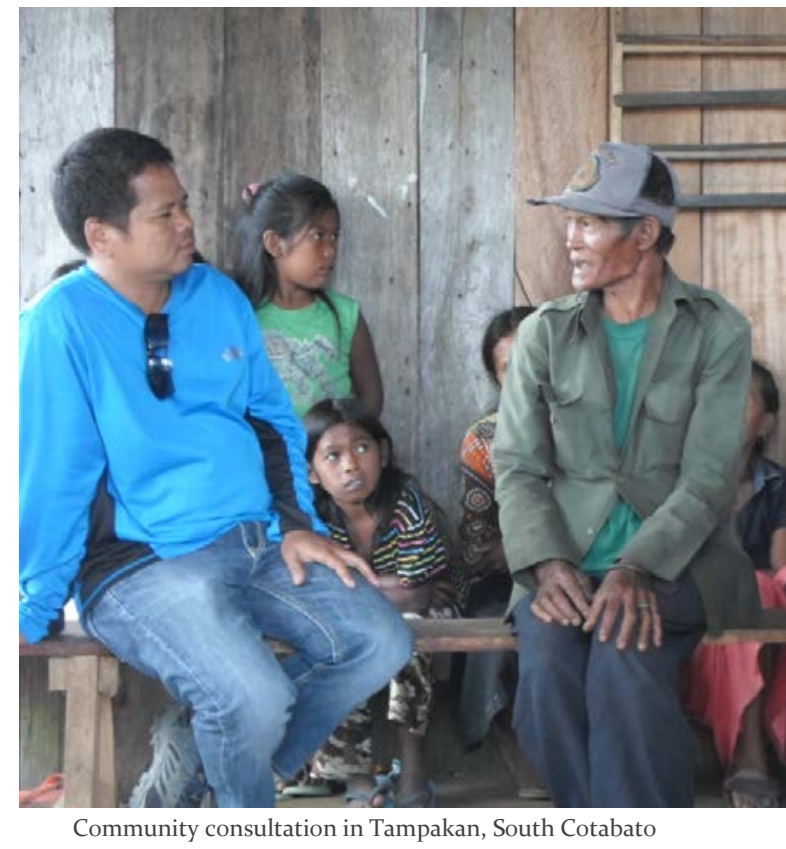

- MOAs involving mining operations and communities are neither publicly available nor readily accessible. For a variety of reasons, including confidentiality and liability, the NCIP, companies, and communities generally appear reluctant to publicize these. FPIC processes and MOAs thus have not been subjected to regular and rigorous monitoring and analysis.

- Different institutions, agencies, and local government units are involved in each mining project. While their mandates are provided by separate laws, there is a considerable degree of jurisdictional overlap. Conflicting or inconsistent mandates from different government institutions contribute to uncertainty for both communities and investors.

There is limited mining-related expertise within the NCIP; the lack of financial, legal, and technical capacity on mining operations and the negotiation of community agreements constrains the institution's ability to provide sustained support for indigenous communities. 
The effectiveness of socioeconomic and environmental safeguards provided in the country's legal framework for mining is significantly hampered by the aforementioned legal and regulatory challenges, information gaps, and capacity constraints. Moreover, a considerable degree of legal uncertainty hangs over the Philippine mining sector. A moratorium on new mineral agreements has been imposed while revisions to their revenue structure are under consideration following EO 79, and a Supreme Court challenge to the Mining Act is pending. Critical issues, such as the vulnerability of undocumented customary rights or the lack of clarity between ownership regimes, will persist. Addressing these challenges through legal reforms, institutional strengthening, and capacity-building will require political will, financial resources, and strategic programs sustained over time.

In the context of legal, regulatory, and information gaps as well as institutional capacity constraints, community agreements or MOAs can potentially address these uncertainties to protect the community's interests as well as those of other stakeholders. This would be possible if a MOA is vigorously negotiated by subject-matter expert advocates for or within the community, and if it clarifies ownership and mining rights while adhering to international standards and best practices on, among others, revenue allocation, compensation and benefits, compliance monitoring, and trust fund management.

FPIC is the vehicle through which indigenous peoples can enforce their right to the equitable and fair sharing of benefits from their natural resources, captured in a Memorandum of Agreement that is mutually agreed upon with the investor. ${ }^{108}$

Companies themselves retain legal experts and other financial and technical advisers to negotiate the agreements required for a project. The expenses for such legal representation and expert advice are project costs that companies normally factor into their balance sheets. Communities, on the other hand, are not similarly situated. They typically have little to no access to credit, nor do they have the independent financial means to retain the advice of legal or other experts.

The company may be open to covering the expenses for a community's legal representation, given that these are clearly a cost of the project as well. Direct funding provided by a company for the legal advocate of the party with whom it is negotiating raises potential conflicts of interest, however, and may taint the credibility of the process and independence of the representation.

Government institutions such as the NCIP may take on this role, although its regulations assign their legal officer to draft the terms agreed to by the community and not to represent the community in negotiations nor to advocate for its interests. Moreover, the agency understandably lacks the human resources and capacity to negotiate and monitor complex mining-related contracts. Ad hoc grants may be available to fund a community's negotiating process, as may voluntary services by legal aid groups. These forms of assistance are typically more available to governments, and where these may be extended directly to a community, the funding and legal services required over time to address the complexities and areas of expertise needed for comprehensive negotiations will be immensely challenging.

It is thus imperative for communities to have access to new and additional sources of financial and technical assistance - independent of governments, companies, philanthropic organizations, or volunteer legal aid groups - through which they can strengthen their capacity to undertake consultative and consent processes, gain genuine consensus, competently negotiate community agreements, and sustainably manage mine revenues.

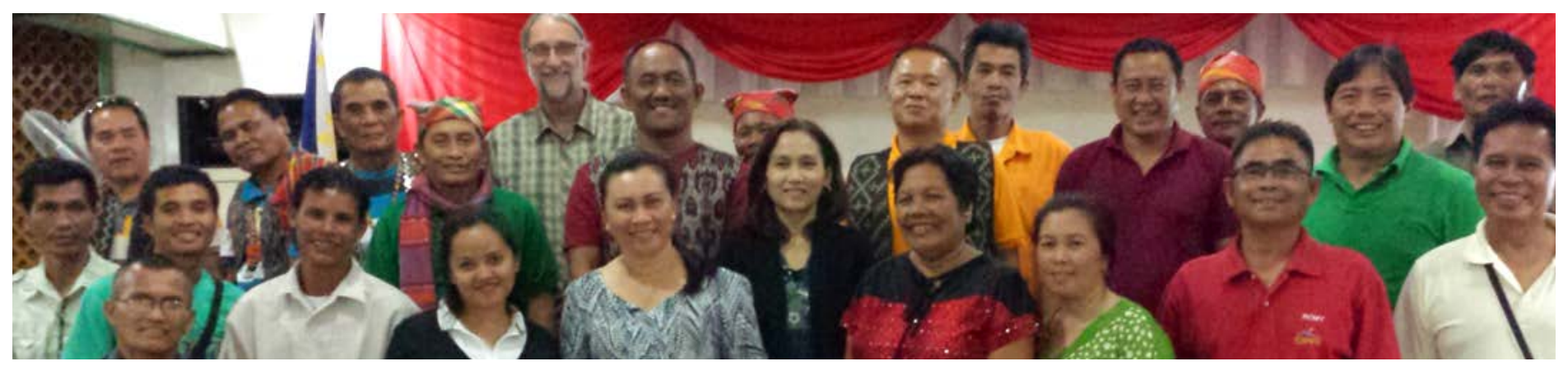

Tribal chieftains, community representatives, and RTC Impact Fund representatives in General Santos City 


\section{CONCLUDING REMARKS}

The expansion of mineral exploration and production in developing countries is a trend that shows no signs of abating, despite cyclical commodity prices or challenging socioeconomic and political conditions in many regions of the world. The demand for and consumption of metals underlie practically every facet of modern life.

The Rio+20 World Conference on Sustainable Development, "The Future We Want," notes that mining offers the opportunity to catalyze broad-based economic development, reduce poverty, and assist countries in meeting development goals when managed effectively and properly. ${ }^{109}$

Rather than serving as an engine for sustainable growth, however, the overlap of large-scale mining and communities in remote rural areas can turn into a collision of economic and cultural interests, characterized by environmental damage, corruption, work stoppages, lost livelihoods, social conflict, and even violence. Mining is inherently technical and complex, often involving a large footprint that may be incompatible with other land uses. Communities need access to comprehensive and objective information about the advantages and disadvantages of each project. ${ }^{110}$

The areas inhabited by the Balatoc indigenous communities in northern Philippines and the $\mathrm{B}^{\prime}$ laan indigenous communities in the southern island of Mindanao have abundant mineral resources long sought by several companies. There are and will likely always be division on whether mining should proceed there. One perspective was expressed by an elderly Balatoc member: "I have grown old hearing about all the mineral wealth under the land where we live, and I am tired of being poor."

The challenge remains, however, of determining whether and how mining can be a viable and sustainable option for him and his community given that local and indigenous communities have been or might be excluded from large-scale investment and development decisions.

International principles and national legal frameworks in democratic societies recognize fundamental human rights, the right of public participation, and the right of people to be consulted in decisions that will affect them. In operationalizing these principles, this paper submits that consultation requirements, consent processes, and community agreements can help communities assert their rights to the equitable sharing of benefits from natural resource wealth.

Capacity-building for communities will be necessary in order for agreements to be effective and sustainable, however, and there do not appear to be strategic approaches through which communities can gain a better understanding of the mining sector and strengthen their capacities to engage in consultative processes, negotiate agreements, and monitor and manage mine revenues.

Finding appropriate ways to provide communities with access and financing to obtain independent expert advisers in the negotiation of community agreements remains a key challenge, one that this paper proposes to address by considering social impact investments. "The purpose is empowerment, where the community ultimately makes the choice. It is important to have the resources to get to where you want to be, noting that "even mining companies need to hire lawyers and othe r experts to help them with negotiations." 111

Impact investments through loans or other financing vehicles could assist communities with building capacity and retaining competent and credible legal and other representatives to negotiate on a knowledgeable, professional, and equal basis with mining companies or governments. Such investments would aim to help project managers mitigate adverse impacts while empowering communities to assert their rights, negotiate in furtherance of their interests, strengthen capacity to monitor projects and manage mine revenue, and maximize project benefits over the long term.

The potential role of social impact investments and PRIs in the negotiation of community agreements is largely uncharted territory. Implementation carries a range of risks, including the reality that even if a community and company may initially agree on a mining project, it does not necessarily mean that the process will result in a negotiated agreement.

Even when a community agreement is successfully negotiated, other factors may delay or stop project implementation, thus impacting and possibly even foreclosing a financial return on investment. Given the importance of achieving social goals through strengthened community capacity, however, impact investments can be more tolerant of financial risks and pioneering efforts on challenging and complicated issues.

As an innovative approach to providing financing where none typically exists, social impact investments and PRIs present a unique opportunity to empower communities as decision-makers, support genuine self-determination, and enable them to create and conserve sustainable benefits for themselves and for future generations. 


\section{NOTES}

1. United States Geological Survey. 2015. "Mineral Commodity Summaries."

2. British Geological Survey. 2015. "World Mineral Production 2009-13."

3. Özkaynak, Begüm, Beatriz Rodriguez-Labajos, and Cem Iskender Aydın. 2015. "Towards Environmental Justice Success in Mining Conflicts: An Empirical Investigation." EJOLT Report 14, April 8.

4. As used in this paper, the "mining industry" refers to large multinational mining companies, state-owned enterprises, junior exploration companies, mine operators, small-scale miners, and service providers. The "mining sector" is used generally to refer to the mining industry and other stakeholders involved in managing mineral development, such as government institutions.

5. Ernst \& Young and Behre Dolbear have consistently rated social issues as being among the top business risks facing the mining sector. The Fraser Institute noted that over $36 \%$ of companies surveyed agreed that public opposition had affected their permitting or approval processes. A 2009 risk analysis by Experts in Responsible Investment Solutions found that 250 large-cap companies with a total market value of \$2.7 trillion have high to medium risk exposure to indigenous peoples in the form of lawsuits, activist campaigns, demonstrations, occupations, and in worst cases, violence.

6. Chatham House. 2013. "Revisiting Approaches to Community Relations in Extractive Industries: Old Problems, New Avenues?"

7. Ibid.

8. World Bank. 2012. Africa Pulse.

9. Holden, William, and R. Daniel Jacobson. 2007. "Mining Amid Armed Conflict: Nonferrous Metals Mining in the Philippines." The Canadian Geographer 4: 477. DOI: 10.1111/j.1541-0064.2007.00193.x.

10. Foti, Joseph, and Lalanath de Silva. 2010. A Seat at the Table: Including the Poor in Decisions for Development and Environment. World Resources Institute.

11. United Nations Development Programme. 2012. "Strategy for Supporting Sustainable and Equitable Management of the Extractive Sector for Human Development."

12. See http://www.voluntaryprinciples.org/.

13. These principles were unanimously endorsed by the UN Human Rights Council in 2011. A UN Guiding Principles Reporting Framework has also been developed. See www.shiftproject.org/project/human-rights-reporting-and-assurance-frameworks-initiative-rafi.

14. While there is no established definition of "indigenous peoples," they generally identify as such, have historical continuity with societies that inhabited an area prior to the arrival of dominant colonial or settler societies, have strong links to traditional lands and natural resources, and resolve to preserve the languages, cultures, and sociopolitical and economic systems that set them apart from dominant societies. See, for example, http://www.un.org/esa/socdev/unpfii/documents/5session factsheet1.pdf.

15. See www.equator-principles.com. Other multilateral financing institutions have adopted similar safeguard policies, including the Inter-American Development Bank (2006), the Asian Investment Bank (2007), and the European Investment Bank (2009). The African Development Bank is the only multilateral financing institution without a separate Indigenous Peoples policy.

16. See http://icmm15ipg.interactiveinvestor.com.au/

17. See http://www.icmm.com/publications/icmm-position-statement-on-indigenous-peoples-and-mining.

18. Torvik, Ragnar. 2009. "Why Do Some Resource-Abundant Countries Succeed While Others Do Not?" Oxford Review of Economic Policy 25 (2).

19. Minerals Council of Australia Initiative. 2005. "Enduring Value: The Australian Minerals Industry Framework for Sustainable Development: Guidance for Implementation."

20. View expressed by Atty. Gerthie Mayo-Anda, Executive Director of the Environmental Legal Action Center, a Philippine CSO.

21. View expressed by Atty. Jeanette Florita, Legal Affairs Officer of the Philippine National Commission on Indigenous Peoples.

22. The World Bank Group consists of the International Bank for Reconstruction and Development/International Development Association, the IFC, and the Multilateral Investment Guarantee Agency.

23. World Bank. 2012. "World Bank Group in Extractive Industries: 2012 Annual Review." Washington, D.C.

24. This fund has a budget of US\$25 million, contributed by Australia, the EU, the Netherlands, Norway, Switzerland, Kuwait, and Oman. See https://www.imf.org/external/np/otm/2010/110110.pdf.

25. See www.mmdaproject.org.

26. The Vale Columbia Center on Sustainable International Investment and the Humboldt-Viadrina School of Governance. 2014. "Matrix of Major Negotiation Support Initiatives." See http://ccsi.columbia.edu/files/2013/11/VCC-Compilation-of-NSIs-April-2014.pdf.

27. The Fraser Institute. N.d. "What are Impact and Benefit Agreements?” Accessed February 5, 2015. http://www.miningfacts.org/Communities/ What-are-Impact-and-Benefit-Agreements-\%28IBAs\%29/. 
Back to Table of Contents

Community Agreements and Mining: A New Frontier for Social Impact Investments | 23

28. Anaya, James. 2013. "Study on Extractive Industries and Indigenous peoples." Report to the Human Rights Council A/HRC/24/41, 2013: 61.

29. Chatham House 2013, 10.

30. United Nations Development Programme, 2012.

31. The World Bank Group. 2011. "The World Bank Group in Extractive Industries 2011 Annual Review."

32. The EITI, for example, is governed in each country by a multi-stakeholder group with representatives from government, industry, and civil society. A country's work plan must include sustained capacity-building for stakeholders on financial literacy, revenue management, and other aspects of extractive industries. Specific training and workshops are incorporated to strengthen civil society participation.

33. Formerly Revenue Watch Institute.

34. Impact investments are distinct from the more passive or indirect "socially responsible investments" in companies or projects that perform well socially or environmentally, or which conversely avoid investments in companies that do not.

35. Monitor Institute. 2009. "Investing for Social and Environmental Impact. A Design for Catalyzing an Emerging Industry," 5.

36. Northern Trust. 2013. "Impact Investing: A Guide for Philanthropists and Social Investors."

37. See $\$ 4944$ of the Internal Revenue Code and $h$ ttp://www.irs.gov/Charities-\&-Non-Profits/Private-Foundations/Program-Related-Investments, accessed March 15, 2015. Like grants, PRIs count toward a foundation's annual 5\% payout. Unlike traditional investments, they are exempt from the excess business holdings tax on equity investments of $20 \%$ or more in for-profit ventures and from the jeopardizing tax on investments that endanger a foundation's sustainability.

38. Lilly Family School of Philanthropy. 2013. "Leveraging the Power of Foundations: An Analysis of Program-Related Investing." Indiana University.

39. Benabentos, Lucia, Justin Storms, Carlos Teuscher, and Jan Van Loo. 2012. "Strategies to Maximize Your Philanthropic Capital: A Guide to Program Related Investments," 12. Mission Investors Exchange.

40. The John D. and Catherine T. MacArthur Foundation provided $\$ 150$ million in grants and a Program-Related Investment in 2007 to support affordable rental housing in the United States, adding \$32.5 million in 2009 to preserve over 70,000 homes in 12 states and cities. Ibid.

41. Motter, Nicole. 2013. "Why Program-Related Investments are Not Risky Business." Forbes, February 21. Accessed March 15, 2015. http:// www.forbes.com/sites/ashoka/2013/02/21/whyprogramrelatedinvestmentsarenotriskybusiness/.

42. See, for instance, Root Capital at http://www.rootcapital.org/.

43. " "Leveraging the Power of Foundations."

44. Ibid., 2.

45. Ibid., 29-30.

46. Ibid., 5, citing the Foundation Center, 2012.

47. Approximately 850 languages are spoken in PNG, for example. See Etnologue: Languages of the World, "Papua New Guinea," http://www. ethnologue.com/country/PG, accessed January 19, 2015. The term "indigenous" is not a distinction generally made in PNG and Ghana, however, unlike in the Philippines and Guatemala. Indigenous peoples in Guatemala, most of Mayan descent, constitute about $43 \%$ of the total population. See “World Directory of Minorities and Indigenous Peoples-Guatemala," Minority Rights Group International, July 2008, http:// www.refworld.org/docid/49749d163c.html.

48. Lugg, Rosemary, Louise Morley, and Fiona Leach. 2007. "Country Profiles for Ghana and Tanzania: Economic, Social, and Political Contexts for Widening Participation in Higher Education." International Journal of Educational Development 29 (1). See also: Viscidi, Lisa. 2004. "A History of Land in Guatemala: Conflict and Hope for Reform." The Americas Program Interhemispheric Resource Center, Silver City, NM.

49. New Agriculturist. 2014. "Country Profiles." Accessed April 7, 2015. http://www.new-ag.info/en/country.php.

50. AID Watch. "Australian Aid to the Pacific (The Pacific Land Program) Briefing: Prepared for the Pacific Regional Representative of the Office of the High Commissioner for Human Rights, January 2009."

51. PNG Mining Act 1992; Ghana's Minerals and Mining Act 703 in 2006 (replacing the previous mining law enacted in 1986); and Guatemala's Mining Law of 1997.

52. United Nations. 2010. "A Report on Ghana's Mining Sector for the $18^{\text {th }}$ Session of the UN Commission on Sustainable Development." Accessed December 10, 2014. http://www.un.org/esa/dsd/dsd aofw ni/ni pdfs/NationalReports/ghana/Mining.pdf.

53. Amponsah-Tawiah, Kwesi. 2011. "The Mining Industry in Ghana: A Blessing or a Curse." International Journal of Business and Social Science 2 (12).

54. Bermúdez-Lugo, Omayra. 2006. "The Mineral Industry of Ghana.” 2006 Minerals Yearbook, United States Geological Survey.

55. Ibid.

56. Ibid.

57. Invest in Guatemala. "Mining." Accessed January 5, 2015. http://www.investinguatemala.org/en/areas-de-inversion/mining. 
58. Ibid.

59. The Corruption Perceptions Index is released annually by Transparency International. It is "based on expert opinion around the world [and] measures the perceived levels of public sector corruption worldwide." See www.transparency.org.

60. This index is an annual report published by Fund for Peace that uses 12 factors to determine the rating for each nation, including indicators such as security threats, group grievances, and human rights violations. For the 2014 Index, see http://library.fundforpeace.org/library/cfsir1423-fragilestatesindex2014-06d.pdf.

61. Veit, Peter. 2012. "Overlapping Land and Natural Resource Property Rights in Africa." World Resources Institute.

62. The Independent State of Papua New Guinea. “Mining Act 1992 and Regulation.” Accessed January 20, 2015. http://www.mra.gov.pg/Portals/2/Publications/MINING ACT\%201992.pdf.

63. Elias, Silvel, and Geisselle Sanchez. 2014. "Country Study: Guatemala." Americas Quarterly, Consulta Previa and Investment Issue, Spring. Accessed April 7, 2015. http://www.americasquarterly.org/content/country-study-guatemala.

64. For example, the UNDP introduced a program called "Strengthening of Civilian Power and the Role of the Armed Forces in a Democratic Society (1996)" which acts as a bridge between civil society and the Guatemalan government; see: Pillay, Rajeev. 2006. "Evaluation of UNDP Assistance to Conflict-Affected Countries: Case Study Guatemala." United Nations Development Programme. Accessed November 28, 2014. http://web.undp.org/evaluation/documents/thematic/conflict/Guatemala.pdf.

65. Ibid.

66. Aubynn, Toni. 2013. "Mining and Sustainable Development: The Case of Ghana." Ghana Chamber of Mines. Accessed October $21,2014$. http://im4dc.org/wp-content/uploads/2013/07/Mining-and-Sustainable-Development-Ghana.pdf.

67. Guatemalan law has already established such a fund in the oil and gas sector, the National Economic Development Fund, or FONPETROL. Pursuant thereto, $5 \%$ of royalties from petroleum production are distributed to Community Councils of Development along with $3 \%$ for environmental protection projects.

68. Statistics in this section are taken from: (1) the National Statistical Coordination Board of the Philippine Statistics Authority-www.nscb.gov.ph; (2) The Philippine Department of Trade and Industry-www.dti.gov.ph; (3) The Philippine Mines and Geosciences Bureau-www.mgb.gov.ph; and (4) "The Fifth National Report to the Convention on Biological Diversity 2014,"prepared by the Biodiversity Management Bureau of the Philippine Department of Environment and Natural Resources.

69. Equivalent to 30 million hectares or almost 116,000 square miles. An archipelago in Southeast Asia, the Philippines is bordered on the west by the South China Sea, on the east by the Philippine Sea and the Pacific Ocean, on the north by the Balintang Channel, and on the south by the Sulu-Celebes Sea.

70. The last census in 2010 reported a population of 92 million, at a rate of growth of $1.9 \%$ between 2000 and 2010 .

71. The national poverty rate is $25 \%$, with some rural areas experiencing rates as high as $60 \%$. The unemployment rate stands at around $6 \%$ (2014); GDP per capita is US\$3,300, while average annual family income is less than US\$5,000 (2009).

72. "Philippines: Communist Rebels Target Civilians." Human Rights Watch, October 5, 2011. Accessed April 7, 2015. www.hrw.org/ news/2011/10/05/philippines-communist-rebels-target-civilians.

73. Holden and Jacobson, 481. See also the website of the Philippine Office of the Presidential Advisor on the Peace Process at www.opapp.gov. ph.

74. Negotiations were stalled in particular by the tragedy resulting from a police operation carried out in early 2015 to capture terrorists in the province of Maguindanao. The operation led to a clash with the Moro Islamic Liberation Front and another separatist group, the Bangsamoro Islamic Freedom Fighters, and ended with the deaths of 44 policemen, 17 rebels, and 4 civilians.

75. "Armed Conflict Report." 2009. Philippine-CPP/NPA. Accessed April 7, 2015. http://www.justice.gov/eoir/vll/country/armed conflict report/ Philippines.pdf.

76. Holden and Jacobson, 486. The literature on guerrilla warfare shows that mountainous terrain is significantly related to higher rates of civil war.

77. Australia-New Zealand Chamber of Commerce Philippines.

78. Wetzlmaier, 335

79. A Filipino corporation must be at least $60 \%$ Filipino-owned.

80. See http://www.mgb.gov.ph/lptt.aspx.

81. Philippine Investment Priorities Plan, 2013.

82. Philippine Extractive Industries Transparency Initiative Report 2014. See http://www.ph-eiti.org/document/EITI-Report/First-Country-Report/ PH-EITI Report Volume 1 Contextual Info final.pdf.

83. See http://www.mgb.gov.ph/Files/Statistics/MinerallndustryStatistics.pdf.

84. Executive Order No. 79, "Institutionalizing and Implementing Reforms in the Philippine Mining Sector, Providing Policies and Guidelines to 
Ensure Environmental Protection and Responsible Mining in the Utilization of Mineral Resources."

85. View expressed by Undersecretary Analiza Teh from the Department of Environment and Natural Resources.

86. Republic Act No. 8371, "An Act to Recognize, Protect and Promote the Rights of Indigenous Cultural Communities/Indigenous Peoples, Creating A National Commission On Indigenous Peoples, Establishing Implementing Mechanisms, Appropriating Funds Therefor, And For Other Purposes," 1997.

87. According to the IPRA, ancestral domains cover not only the physical environment and natural resources, but the indigenous community's spiritual and cultural bonds to the areas. Ancestral lands refer to areas that have been subjected to occupation or cultivation.

88. Ancestral domains and lands are private but community property belonging to all generations and cannot be sold, disposed of, or destroyed. Vested property rights existing at the time of IPRA's effectivity, however, shall be respected.

89. The IPRA defines FPIC as the consensus of all of the members to be determined in accordance with their customary practices, free from any external interference, obtained after fully disclosing the intent and scope of an activity, in a language and process understandable to the community. Customary laws refer to the rules and practices continually observed by the community. Indigenous peoples have the right to use their customary laws within their communities as may be compatible with the national legal system and internationally recognized human rights.

90. The ADSDPP refers to the community's plans for the sustainable development of their land and resources (natural, cultural, and human) based on their indigenous knowledge systems and practices.

91. If the area covered by an application or renewal of a mineral concession is not found to overlap with or affect any ancestral domain, determined through a Field-Based Investigation, the NCIP Regional Director shall issue a Certificate of Non-Overlap with the concurrence of the concerned NCIP Commissioner.

92. In cases where a mining application overlaps with ancestral domains or lands, an FPIC team formed by the NCIP Regional Director, consisting of NCIP personnel and indigenous community leaders, shall convene an assembly to validate the Field-Based Investigation Report and verify community leadership, decision-making processes, the community census, the area affected, the existence of any boundary conflicts, and other pertinent issues. A second community assembly shall provide an open forum for the community to present their concerns and to reach consensus on a proposed mining project. The applicant shall present its project, the operational plan, the positive and adverse impacts on the community, and mitigation measures. The FPIC team may seek the advice of independent experts to discuss, among others, the EIA if it is available. Input from other stakeholders will be invited, including LGUs and CSOs. The community is expected to deliberate over these issues and to render a decision within two months of the second assembly.

93. Under the Mining Act and the IPRA, royalties shall form part of a trust fund for the socioeconomic well-being of the communities, to be managed and utilized by them.

94. View expressed by Atty. Jonas Adaci, Director of the NCIP Ancestral Domains Office.

95. View expressed by Cristina Pimentel from the CSO coalition Bantay Kita (Revenue Watch).

96. Perspectives shared by Atty. Mary Grace Ellen S. Villanueva, Executive Director, Legal Rights and Natural Resources Center.

97. Information provided by Atty. Gerthie Mayo-Anda, Executive Director of the Environmental Law Action Center.

98. First Philippine Report to the EITI, 2012. See http://www.ph-eiti.org/\#/EITI-Report/First-Country-Report.

99. Ibid.

100. Deutsche Gesellschaft für Internationale Zusammenarbeit. 2013. "Assessing Free and Prior Informed Consent (FPIC) Implementation in the Philippines." https://www.giz.de/en/downloads/giz2013-en-assessing-free-and-prior-informed-consent-fpic-phillipinen.pdf.

101. View expressed by Atty. Gerthie Mayo-Anda, Executive Director of the Environmental Law Action Center.

102. Information provided by Atty. Jonas Adaci, Director of the NCIP Ancestral Domains Office.

103. Information provided by Percy Brawner, NCIP Commissioner.

104. Experience shared by Atty. Jonas Adaci, Director of the NCIP Ancestral Domains Office.

105. View expressed by Undersecretary Analiza Teh from the Philippine Department of Environment and Natural Resources.

106. Issue raised by Atty. Julito "Sarge" Sarmiento, Partner, Puno and Puno Law Offices.

107. Issue raised by Era España, NCIP Commissioner, citing her experiences in the provinces of South Cotabato and Sarangani.

108. "Assessing Free and Prior Informed Consent (FPIC) Implementation in the Philippines," 2.

109. United Nations Conference on Sustainable Development. 2012. "The Future We Want." Resolution adopted by the General Assembly, A/ $\mathrm{RES} / 66 / 288$.

110. View expressed by Engr. Rod Velasco, Chief, MGB.

111. View expressed by Antonio G.M. La Viña, Dean of the Ateneo School of Government. 
RTC Impact Fund

송 one earth 